Article

\title{
Anatomical and Biochemical Traits Associated with Field Resistance of Onion Cultivars to Onion Thrips and the Effect of Mechanical Injury on the Level of Biochemical Compounds in Onion Leaves
}

\author{
Maria Pobożniak 1,*(D), Marta Olczyk ${ }^{1}$ (D) , Tomasz Wójtowicz ${ }^{2} \mathbb{D}$, Iwona Kamińska ${ }^{1}$ (D) Ewa Hanus-Fajerska ${ }^{1}$ (D) \\ Anna Kostecka-Gugała ${ }^{3}$ and Michał Kruczek ${ }^{3}$ \\ 1 Department of Botany, Physiology and Plant Protection, Faculty of Biotechnology and Horticulture, \\ University of Agriculture in Krakow, 31-425 Krakow, Poland; m_olczyk@poczta.fm (M.O.); \\ i.kaminska@urk.edu.pl (I.K.); e.hanus-fajerska@urk.edu.pl (E.H.-F.) \\ 2 Department of Plant Breeding, Physiology and Seed Science, Faculty of Agriculture and Economics, \\ University of Agriculture in Krakow, 31-140 Krakow, Poland; tomasz.wojtowicz@urk.edu.pl \\ 3 Department of Plant Biology and Biotechnology, Faculty of Biotechnology and Horticulture, University of \\ Agriculture in Krakow, 31-425 Krakow, Poland; anna.kostecka-gugla@urk.edu.pl (A.K.-G.); \\ kruczek.michael@gmail.com (M.K.) \\ * Correspondence: maria.pobozniak@urk.edu.pl; Tel.: +48-12-662-52-58
}

check for updates

Citation: Pobożniak, M.; Olczyk, M.; Wójtowicz, T.; Kamińska, I.; Hanus-Fajerska, E.; Kostecka-Gugała, A.; Kruczek, M. Anatomical and Biochemical Traits Associated with Field Resistance of Onion Cultivars to Onion Thrips and the Effect of Mechanical Injury on the Level of Biochemical Compounds in Onion Leaves. Agronomy 2022, 12, 147. https://doi.org/10.3390/ agronomy 12010147 Academic Editors: Jaime Carrasco and Francisco J. Gea

Received: 22 November 2021

Accepted: 4 January 2022

Published: 8 January 2022

Publisher's Note: MDPI stays neutral with regard to jurisdictional claims in published maps and institutional affiliations.

Copyright: (C) 2022 by the authors. Licensee MDPI, Basel, Switzerland. This article is an open access article distributed under the terms and conditions of the Creative Commons Attribution (CC BY) license (https:// creativecommons.org/licenses/by/ $4.0 /)$.

\begin{abstract}
Thrips tabaci Lind. is a global pest and also represents a serious threat to onion production in Poland. In 2 years (2015-2016) of field studies, 8 onion cultivars were evaluated to characterize the resistance to onion thrips and to determine if any biochemical and anatomical features of onion plants are associated with antixenotic and/or antibiotic mechanisms of resistance. Additionally, the influence of mechanical injury on the content of several biochemical compounds in onion leaves was made. The resistance to thrips colonization during the migration period, abundance, and thrips damage throughout the whole vegetation season was determined. We identified two cultivars, Tẹcza and Wenta, resistant to thrips colonization and abundance, and one cultivar Wenta resistant to thrips damage. A positive correlation between concentrations of the reducing sugars and thrips abundance and conversely negative relationships between the total phenolic content and thrips damage was confirmed in both years. We suspect that a thinner epidermal layer, a smaller area of epidermal and mesophilic cells, and a lower diameter of vascular bundles may favor the resistance of onion cultivars to thrips. Thrips foraging resulted in a decrease in the content of soluble sugars, sucrose, and plant pigments in the leaves of all onion varieties.
\end{abstract}

Keywords: antixenosis; antibiosis; sugars; phenolics; chlorophyll; carotenoids; epidermis; mesophyll; vascular bundles

\section{Introduction}

Onion is an important vegetable in terms of global production volume. The largest onion-producing countries are China and India, whose combined share of global production is approaching 46.5\% [1]. Among EU member states, most onions are harvested in the Netherlands, Spain, and Poland with 651,349 tons yearly production, putting Poland in 3rd position and constituting approximately $8.3 \%$ of the harvest in the European Union [2].

Onion thrips, Thrips tabaci Lind. is a global pest $[3,4]$ and also represents a serious threat to onion production in Poland [5]. Adults and larvae of onion thrips insert their stylets into the leaves and ingest the content of epidermal and mesophyll cells [6]. The pierced cells collapse or fill up with air, giving the damaged area a silvery appearance [7]. Therefore, damage resulting from injuries caused by thrips appears as silvery patches, streaks on the leaves, or tiny black "tar" spots, which are thrips feces. As a result, the feeding thrips cause 
premature senescence of leaves, reduce the photosynthetic capacity, hinder the transport of nutrients to the bulb, and consequently lead to their distortion and loss of biomass $[3,8]$. Thrips damage can significantly reduce onion yields ranging from $22 \%$ [9], 30\% [10], $35-43 \%$ [11], to up to $60 \%$ [12]. Onion thrips are a vector of Iris yellow spot virus (IYSV) and they spread it efficiently in onion plantations [13]. Moreover, tissue injury that results from thrips feeding causes increased vulnerability to infection by bacterial pathogens such as Pantoea ananatis, P. agglomerans, and P. alli that cause the onion center-rot complex, as well as Alternaria porri, the fungus that in turn causes purple blotch [14,15]. Thus, to prevent the opening of infection pathways, it is usually necessary to combat onion thrips, which requires frequent applications of insecticides [16], with the unfortunate consequence of increased resistance to commonly used pyrethroids and organophosphates [17,18], methomyl, and oxamyl (carbamates), abamectin [19], and spinetoram [20].

Consumer demand for high-quality onions, free from pesticide residues are currently increasing. For this reason, a growing number of onion growers are choosing the cultivation of resistant and/or tolerant cultivars as an important preventative element of Integrated Plant Management (IPM) [21].

Resistant cultivars have physical and/or chemical traits that protect them against pest infestation and feeding [22]. The cultivation of cultivars with even partial resistance is considered to be the best method of pest control [23]. Resistance mechanisms can be classified as antixenosis and antibiosis. These insect plant host relationships relate to two different events, namely the search by an insect for the plant and its unacceptance (antixenosis), and the impact of the plant as food on the pest (antibiosis) [24,25]. Plant antixenosis negatively affects insect colonization processes, resulting in a reduced initial infestation level, due to a feature (or set of features) that deters insects from settling and feeding [24]. The expression of antixenosis in genotypes may be a consequence of morphological, physical, and chemical features in plants and mainly affects the visual [26,27] and olfactory stimuli [28] involved in the host-finding behavior of thrips. In contrast, antibiosis negatively affects insect pest biology and their progeny (survival, development, and reproduction and are strongly influenced by the poor plant's nutritional quality (inadequate composition and concentration of soluble proteins and carbohydrates) [29,30], primary metabolites (e.g., lectins, proteinase, and amylase inhibitors), and secondary plant compounds (e.g., chlorogenic acid, glycoalkaloids, flavonoids, jasmonic acid) [31,32].

In the multi-cultivar planted trial, i.e., in a choice situation, some of the differences in thrips population development can be attributed to differences in thrips preference and/or host plant resistance. Under environmental conditions, the measurement of insect population size in the field is used by entomologists as an opportunity to conduct the first stage of selection of susceptible or resistant plant material. The existence of plant resistance can indicate that the plant possesses a mechanism of antixenosis and/or antibiosis. The development and survival of thrips on crops in the field not only depend on the resistance of host plants but are also highly influenced by environmental conditions, including temperature, wind, frequency and the level of precipitation during the vegetation phase [33], as well as predators [34] and parasitoids [35].

Currently, there are no known onion cultivars that are very highly resistant to onion thrips, but some of them show a certain level of resistance, mainly related to the morphological, physical, and chemical characteristics of onion plants. In studies conducted in New York (USA), 15 cultivars considered as partially resistant to thrips were identified (out of 54 tested onion cultivars), namely, OLYS05N5, Tioga, Peso, Gramero, Cometa, Medeo, T-433, Colorado 6, Mesquite, Acero, White Wing, Calibra, Delgado, NMSU 03-52-1, and Vaquero $[13,26]$. Results obtained by Diaz-Montano et al. $[13,26]$ indicated that all of these onion varieties had yellow-green leaves and showed a strong antixenotic effect; furthermore, the last six cultivars showed an intermediately high antibiotic effect on onion thrips. Moreover, subsequent research showed that onion varieties with lighter-green and glossy leaves usually supported a lower number of onion thrips and suffered less feeding damage than phenotypes with waxy, bluish-green leaves [8,36]. According to Damon 
et al. [36], the light-green leaf colour in resistant onion varieties has been associated with the amount and chemical composition of epicuticular waxes on foliage. Varieties resistant to onion thrips with glossy (low wax) and semi-glossy (intermediate wax) phenotypes had much lower amounts of the ketone hentriacontanone-16(H-16) and higher amounts of other waxes such as alkanes and fatty alcohols compared to varieties with phenotypes susceptible to thrips feeding [37]. In Brazil, the antixenotic resistance of the variety Alfa São Francisco RT was associated with certain morphological traits, a wider central angle $\left(16.4^{\circ}\right)$, a thinner cuticle, a larger amount of epicuticular waxes, and stomata on the surface of leaves, while the antibiotic resistance of BR 29 and Sirius was likely due to the presence of resistance-conferring substances or high amounts of some component in the chemical composition of plants [38]. Alimousavi et al. [39] also confirmed that in the four Iranian onion cultivars Meshkan, Sefid-e-Kurdistan, Sefid-e-Qom, and Eghlid, a large angle between the two innermost emerged leaves, especially in the young plant, help to restrict the thrips population by reducing the protective environment to a minimum. In Tanzania, out of 163 onion accessions, only three onion thrips resistant accessions (VI038512, VI038552, and AVON 1067) were identified [40]. The explanation of biophysical and biochemical bases of resistance revealed that a wider leaf angle, higher leaf toughness, and higher amount of total phenolics influenced the defensive reaction of these onion accessions to thrips feeding. Varietal preference and the susceptibility of onion plants to onion thrips have been documented in Poland, but only some traits were investigated to explain this preference [41,42].

An in-depth understanding of the features underlying the resistance of onion cultivars to thrips is essential for breeders to improve the resistance of onion cultivars to this pest. Therefore, this research was conducted with the following aims: (1) to identify onion cultivars possibly resistant to onion thrips infestation in the early growing season, resistant to thrips abundance and damage under field conditions throughout the whole growing season; and (2) to determine whether there is a relationship between any biochemical and anatomical features of onion plants and their resistance to thrips. Additionally, an attempt was made to determine the influence of mechanical damage on the content of several biochemical compounds in the leaves of the onion cultivars examined.

\section{Materials and Methods}

\subsection{Plant Material and Experimental Setup}

All of the Allium cepa L. cultivars applied in this study are recommended for cultivation in central Europe and are commercially available. The seeds were obtained from Polish breeding companies, namely, PlantiCo Zielonki in Stare Babice (mid-early cultivar Alibaba with a white bulb, late cv. Bila, mid-late cultivars Kristine, and Niagara $F_{1}$ with a yellow bulb and late cv. Wenta with a red bulb), Polan in Krakow (mid-early cv. Karmen with a red bulb and mid-late Polanowska with a yellow bulb) and Spójnia in Nochowo (early cv. Tęcza with a yellow bulb). Preliminary screening, of a large number of new and $\mathrm{F}_{1}$ hybrid cultivars, conducted beforehand indicated that the eight selected cultivars might possess some traits responsible for resistance or tolerance to the onion thrips [41].

Trials were conducted at the Experimental Station of the University of Agriculture in Krakow which is located in Mydlniki (southern Poland, Krakow District, $50^{\circ} 04^{\prime} \mathrm{N}, 19^{\circ} 51^{\prime} \mathrm{E}$, $207 \mathrm{~m}$ above sea level). The cultivation was carried out on a typical brown soil with a $\mathrm{pH}$ of 6.5 with $18 \mathrm{~g} / \mathrm{kg}$ organic carbon content; all agronomic treatments were carried out following the recommendations for this crop type. In the spring of each trial year, plots were fertilized according to the Integrated Production recommendations for onion in the field. No chemical treatments were applied; weeds were removed mechanically and manually.

The experimental design was arranged in a randomized complete blocks (RCB) design with four blocks. The plot size was $12 \mathrm{~m}^{2}(3 \times 4 \mathrm{~m})$, with a distance between the plots of $1 \mathrm{~m}$. Seeds were sown (25 kg/ha) in rows, $0.3 \mathrm{~m}$ apart, on 10 April 2015 and 6 April 2016. 
The onion plots were separated from the neighboring crops (potatoes, herbs, red beets, white cabbage, zucchini, and pumpkin) by a $2 \mathrm{~m}$ path.

On-site meteorological data (ambient air temperature and precipitation) were recorded at the trial site from May to September in 2015 and 2016, at 60-min intervals. A HOBO water temperature Pro data logger (Onset Computer Corp., Bourne, MA, USA) was used for this purpose (Figure S1).

\subsection{Field Resistance Experiment}

The identification of resistance to host plant colonization (selection of plants for settlement) and determination of the abundance of the onion thrips throughout the whole season (resistance to thrips abundance) was carried out under field conditions. For this purpose, from June until harvest (end of August) within each testing plot, 10 randomly selected plants per cultivar within every block were taken weekly from the plots and placed into separate zip-lock plastic bags followed by appropriate labeling. The collected material was transported to the laboratory, where larvae and adults of thrips were handseparated from onion plants using a soft brush (size 1) and placed in vials containing $75 \%$ ethanol. Microscopic slides were prepared under laboratory conditions according to the technique described by Zawirska [43]. The taxonomic identification was made based on keys developed by zur Strassen [44] (adults) and Kucharczyk [45] (larvae).

The identification of resistance to thrips damage was determined as the degree of damaged leaf area of onion leaves. For this purpose, every week three leaves (the oldest, the middle-aged, and the youngest) were chosen from each of 10 randomly selected plants harvested from each testing plot. Next, a $10 \mathrm{~cm}$ long segment was cut from the center of each leaf. Then, the onion leaf was sliced open, and the damaged leaf area (silvery spots and white blotches along with the leaves) was estimated and expressed as the percentage of the damaged leaf. In the assessment of the level of field resistance of the assigned cultivars to plant colonization by migrating adult thrips, one indicator was used, namely, the mean number of adult thrips per 10 plants collected during the migration period, which lasted from 24 June to 2 July 2015, and from 16 to 25 June 2016. Based on published data about the effect of temperature on the development of onion thrips [46,47], a degree-day (DD) model was computed for both 2015 and 2016 [42]. The heat sum model predicted the development of onion thrips well, and therefore all adult thrips that were encountered during this sampling event (for both years) can be considered colonizing adults. The seasonal mean number of feeding thrips (adults and larvae) per 10 plants and mean feeding damage expressed as a mean percentage of the damaged leaf area were used as indicators to estimate the field resistance levels throughout the growing season of the onion cultivars tested. A four-grade scale was used to define the value of the indicators (1-4). The highest numbers of points were given to samples with the lowest values for the relevant criteria, i.e., those which demonstrated the highest level of cultivar resistance. Different scales were used for the indicators in each year $(2015 ; 2016)$ - the reason for this was the significant difference in the abundance of the thrips populations observed in each year (Table 1).

Table 1. The number of points assigned to indicators of the field resistance of onion cultivars to Thrips tabaci.

\begin{tabular}{cccccc}
\hline Indicators & Year & \multicolumn{3}{c}{ Scale } \\
\cline { 3 - 6 } & & 4 Points & 3 Points & 2 Points & 1 Point \\
\hline Mean number of migrating adult & 2015 & $0.00-3.75$ & $3.76-6.75$ & $6.76-10.75$ & $>10.75$ \\
thrips per 10 plants & 2016 & $0.00-1.50$ & $1.51-3.50$ & $3.51-5.50$ & $>5.50$ \\
Seasonal mean number of adults and & 2015 & $0.00-7.50$ & $7.51-10.00$ & $10.01-12.00$ & $>12.00$ \\
larvae of thrips per 10 plants & 2016 & $0.00-2.75$ & $2.76-4.75$ & $4.76-7.00$ & $>7.00$ \\
Mean percentage of damaged leaf & 2015 & $0.00-10.00$ & $10.01-13.00$ & $13.01-17.50$ & $>17.50$ \\
area by feeding thrips & 2016 & $0.00-5.00$ & $5.01-6.50$ & $6.51-7.25$ & $>7.25$ \\
\hline
\end{tabular}


Determination of the level of resistance was based on the mean number of points over the two years, assigned separately for the plant colonization by migrating adult thrips, resistance to thrips abundance, and the resistance to thrips damage throughout the growing season. Four levels of field resistance were used to classify the onion cultivars: resistant—with a high degree of field resistance ( $>3.00$ points); moderately resistant—with a moderate degree of field resistance (3.00-2.50 points); susceptible - with a low degree of field resistance (2.49-1.5 points); and highly susceptible - with a very low degree of field resistance ( $<1.5$ points).

The onions were harvested on 10 September in 2015 and 8 September in 2016. As each cultivar has a different yield potential, bulb yields were not compared among cultivars.

\subsection{Biochemical Analyses of Leaves}

For biochemical studies, 6 undamaged plants and 6 damaged onion plants by thrips were taken randomly from each cultivar within every block on 28 July 2015, and 8 August 2016. Two of the middle-aged leaves with injuries caused by thrips of each damaged plant and two healthy leaves from the undamaged plants were taken. Then, the undamaged and damaged leaves were separately cut into approximately $1 \mathrm{~cm}$ pieces, mixed, weighed, freeze-dried, and kept in the dark at room temperature. The lyophilisates were then ground using an electric mill and $0.5 \mathrm{~g}$ of the ground lyophilisate was homogenized with $90 \%$ ethanol for approximately $30 \mathrm{~s}$ in a porcelain mortar. The obtained solutions were filtered under pressure through a G4-type sintered glass funnel (pore size: 10-16 $\mu \mathrm{m}$ ), poured into polypropylene tubes, and filled to the final volume of $25 \mathrm{~mL}$ with the solution obtained by washing the mortar several times with the extractant. The extracts were stored in the dark at $4{ }^{\circ} \mathrm{C}$. Using them, all analyses of the biochemical parameters were performed. Four repetitions of measurements of all biochemical parameters were carried out for each plot in both years for undamaged and damaged onion leaves.

\subsubsection{Total Soluble Sugar Content}

The total soluble sugar content was determined by the anthrone test [48]. The extracts for analysis were diluted $(0.02 \mathrm{~mL}$ of the extract and $4.98 \mathrm{~mL}$ of water) and the anthrone reagent $\left(0.2 \mathrm{~g}\right.$ anthrone in conc. $\left.\mathrm{H}_{2} \mathrm{SO}_{4}\right)$ was added and thoroughly mixed. The samples were then incubated at $90 \pm 1{ }^{\circ} \mathrm{C}$ for $15 \mathrm{~min}$. After cooling down, the absorbance of a blue-green complex was measured at $620 \mathrm{~nm}$ (JASCO V-530 UV/Vis spectrophotometer). A 5-point standard curve was prepared using glucose solutions. The data were expressed in grams per $100 \mathrm{~g}$ of fresh plant weight.

\subsubsection{Reducing Sugar Content}

The reducing sugar content was assessed by the hexacyanoferrate assay [49]. Briefly, $0.3 \mathrm{~mL}$ of $0.3 \% \mathrm{~K}_{3}\left(\mathrm{Fe}(\mathrm{CN})_{6}\right)$ and $0.3 \mathrm{~mL}$ of $0.53 \% \mathrm{Na}_{2} \mathrm{CO}_{3}$ solutions were mixed with the extract, $400 \mathrm{x}$ diluted with water, and heated at $90 \pm 1{ }^{\circ} \mathrm{C}$ for $15 \mathrm{~min}$. After cooling, $1.5 \mathrm{~mL}$ of $0.5 \% \mathrm{Fe}_{2}\left(\mathrm{SO}_{4}\right)_{3}$ solution containing $7.5 \mathrm{~mL}$ of $85 \% \mathrm{H}_{3} \mathrm{PO}_{4}$ and $1 \mathrm{~g}$ of acacia gum per $100 \mathrm{~mL}$ was added. After 15-min incubation at room temperature, the absorbance of a blue product, $\mathrm{KFe}\left(\mathrm{Fe}(\mathrm{CN})_{6}\right)$, was measured at $660 \mathrm{~nm}$ (JASCO V-530 UV/Vis spectrophotometer). A 5-point standard curve was prepared using glucose solutions. The data were expressed in grams per $100 \mathrm{~g}$ of fresh plant weight.

\subsubsection{Sucrose Content}

The sucrose concentration was estimated as the difference between the concentrations of the total soluble sugars and the reducing sugars (total sugars—reducing sugars $\approx$ sucrose).

\subsubsection{Total Phenolic Content}

The sum of phenolic compounds was measured according to a Folin-Ciocalteu assay [50]. A $2.4 \mathrm{~mL}$ sample of the extract diluted 10-fold with water was then mixed with $0.25 \mathrm{~mL}$ of $25 \% \mathrm{Na}_{2} \mathrm{CO}_{3}$ and $0.125 \mathrm{~mL}$ of the Folin-Ciocalteu reagent (diluted twice with 
water). The absorbance was measured at $760 \mathrm{~nm}$ after 15 -min incubation at room temperature (JASCO V-530 UV/Vis spectrophotometer). A 5-point standard curve was prepared using gallic acid solutions and the final results were expressed as mg of GAE (gallic acid equivalents) per $100 \mathrm{~g}$ of fresh plant weight.

\subsubsection{Chlorophyll and Total Carotenoid Contents}

For the determination of chlorophyll and total carotenoid contents, the spectrum of the extracts was measured against ethanol in the range of 450-800 nm (JASCO V-530 UV/Vis spectrophotometer). The absorbance values were recorded at 3 wavelengths: 664, 648 and $470 \mathrm{~nm}$. To calculate the content of chlorophyll a, chlorophyll b, and the sum of carotenoids in the plant material, the absorbance values were used in empirical equations [51]:

$$
\begin{gathered}
C \text { chlorophyll } \mathrm{a}=11.75 \cdot A_{664}-2.35 \cdot A_{648} \\
C \text { chlorophyll } \mathrm{b}=18.61 \cdot A_{648}-3.96 \cdot A_{662} \\
C \text { sum of carotenoids }=\frac{1000 \cdot A_{470}-2.27 \cdot C_{\mathrm{chla}}-81.40 \cdot C_{\mathrm{chlb}}}{227}
\end{gathered}
$$

where: $(A)$ measured absorbance, $(C)$ concentration of chlorophylls or carotenoids in the extract $\left(\mathrm{mg} / \mathrm{dm}^{3}\right)$.

The final results were expressed in milligrams per $100 \mathrm{~g}$ of fresh plant weight.

\subsection{Anatomical Studies of Leaves}

For anatomical studies, five-leaf blades from each cultivar were collected on 8 August 2016. Ten fragments, about $10 \mathrm{~mm}$ long were excised from a half-length of each leaf blade. Tissue samples were fixed in a glutaraldehyde solution and washed thoroughly with 0.1-M phosphate buffer. After dehydration in a graded ethanol series, the samples were immersed in acetone and embedded in Epon 812 resin. The sections, $1 \mu \mathrm{m}$ thick, were cut with a diamond knife on a Tesla 490A ultramicrotome, stained with $0.1 \%$ methylene blue, and examined in an Axio Imager M2 (Zeiss), with observations conducted in the bright field. Measurements of leaf blade anatomical parameters on the cross-sections from each leaf were conducted with the use of Image software. The leaf-blade thickness was measured separately along the vascular bundle axis (referred to as max. thickness) and only through the mesophyll layers (referred to as min. thickness). The mean leaf blade thickness was calculated as the arithmetic mean of these values. Furthermore, epidermal cell thickness, perimeter, and area were also measured. Within the mesophyll, the perimeter and area of the cells were estimated, together with the number of cell layers and intracellular spaces. Additionally, measurements of the diameter, perimeter, area, and distance between leaf vascular bundles were made.

\subsection{Studies on the Effect of Mechanical Injury on the Level of Biochemical Compounds in Onion Leaves}

For this study, the total soluble sugar, reducing sugar, sucrose, total phenolic, chlorophyll $a$ and $b$, and the total carotenoid contents in the leaves of onion plants both undamaged and damaged by feeding thrips were compared, in both years.

\subsection{Statistical Analysis}

Statistical analyses were performed with the Statistica 13 software (Dell Inc., Round Rock, TX, USA, 2016). For all one-way ANOVA analyses (the factor was onion cultivar), residual plots were checked for normality of residuals. In the case of the absence of normality, the data regarding the number of thrips were normalized using $\log _{10}(x+1)$ transformation; for the damaged leaf area (\%), arcsine transformation and $\ln$ transformation for the leaf blade thickness and parameters of the leaf's epidermal and mesophyll cells were used. Note that the tables and figures show untransformed data. Multiple comparisons were computed using Duncan's multiple range test $(p<0.05)$. Two-way ANOVA was 
performed with cultivars and damage level of leaves (undamaged/damaged leaves) as the factors for the biochemical data, i.e., the contents of soluble sugars, reducing sugars, sucrose, total phenolic, chlorophylls, and carotenoids in the leaves. When significant effects of damage level on analyzed traits were detected with ANOVA, within each cultivar the control mean (the undamaged leaves) and mean obtained in the damage leaves were compared by Student's $t$-test $(p<0.05)$. The difference between the control (undamaged) leaves and the damaged leaves was recalculated as a percentage of the control value.

To examine the relationship between the number of thrips and the percentage of the damaged leaf area and the sugars and total phenolic contents and some parameters of the leaf's epidermal and mesophyll cells, Pearson's correlation coefficient $(r)$ was calculated; significance was set to $p<0.05$.

\section{Results}

\subsection{Field Resistance Assessment}

Onion thrips population sizes were higher in 2015 than in 2016 when the July and August average temperatures were higher and the total rainfall was lower, which likely contributed to the greater thrips infestation in 2015 (Figure 1a-f and Figure S1).

In both years, significant variability of cultivars was found in terms of the mean number of migrating adults of onion thrips, the seasonal mean number of onion thrips imago and larvae, and seasonal mean number of thrips larvae $(p<0.05)$. The block had no significant effect on the seasonal mean number of thrips larvae $(p=0.475)$ in 2015 , while in 2016 , this factor significantly affected the mean number of migrating adult thrips $(p<0.05)$ (Table S1).

For the year 2015, significantly more migrating adults of onion thrips infested cv. Bila and Niagara $F_{1}$ than the other onion cultivars, except for Karmen, Kristine, and Polanowska. $\mathrm{Cv}$. Wenta was infested with the lowest number of adult thrips during onion plants colonization, followed by Tęcza and Alibaba (Figure 1a). A significantly higher seasonal a mean number of onion thrips adults and larvae throughout the growing season was detected on Karmen and Niagara $F_{1}$ in comparison with the other cultivars, except for Alibaba and Bila. Cv. Tęcza was infested with the lowest number of onion thrips, followed by Wenta and Kristine (Figure 1b). Onion thrips larvae were less abundant than adults on all onion cultivars. Larvae accounted for $20.6-40.4 \%$ of total mean thrips per 10 leaves and values varied by onion cultivar. A significantly higher seasonal mean number of thrips larvae was detected on Alibaba and Niagara $F_{1}$ in comparison with the other cultivars (Figure 1c).

The factorial analyses indicated significant differences in the number of thrips sampled on the different cultivars on most of the sampling dates (Table S2). In late June, two cultivars Tęcza and Wenta were not found to be infested by onion thrips, and in early July pest density was significantly lower on Tęcza, Alibaba, and Wenta in comparison to other cultivars. In July and August, the number of thrips was usually significantly lower on Kristine, Tęcza, and Wenta than on other cultivars (Figure S2).

The mean percentage of damaged leaf area showed significant differences between onion cultivars in terms of susceptibility to thrips damage. There was no block effect on this parameter ( $p=0.530$ ) (Table S1). Cv. Polanowska was significantly the most susceptible to thrips damage than all other cultivars with exception of Teqcza, while the most resistant was Wenta followed by Alibaba, Niagara $F_{1}$, Bila, and Karmen (Figure 2a). 

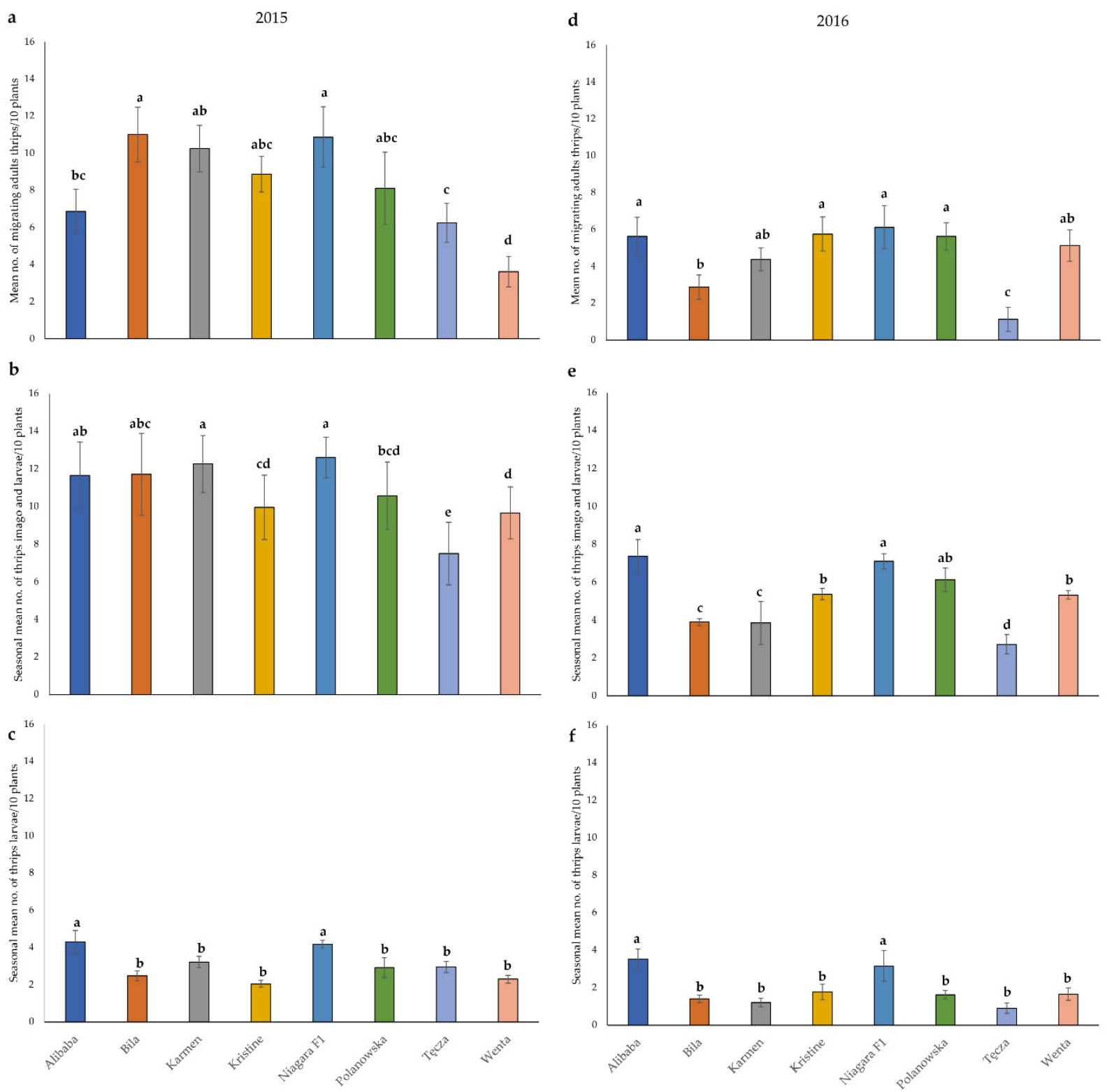

Figure 1. Mean $( \pm \mathrm{SE})$ Thrips tabaci abundance on onion cultivars: (a,d) during onion plants colonization by the adults, $(\mathbf{b}, \mathbf{e})$ throughout the growing season by adults and larvae, and (c,f) by larvae of thrips in 2015 and 2016. Means with the same letters on each bar do not differ significantly (Duncan's multiple range Test, $p<0.05)$.

Despite the fact that according to the statistical analysis, the difference between the percentage of damaged leaf area on the eight onion cultivars was significant only for four of the nine sampling events, it seems that in almost all sampling events Polanowska and Tęcza were the most damaged and Wenta the least damaged in comparison to those others cultivars (Figure S3, Table S2). 

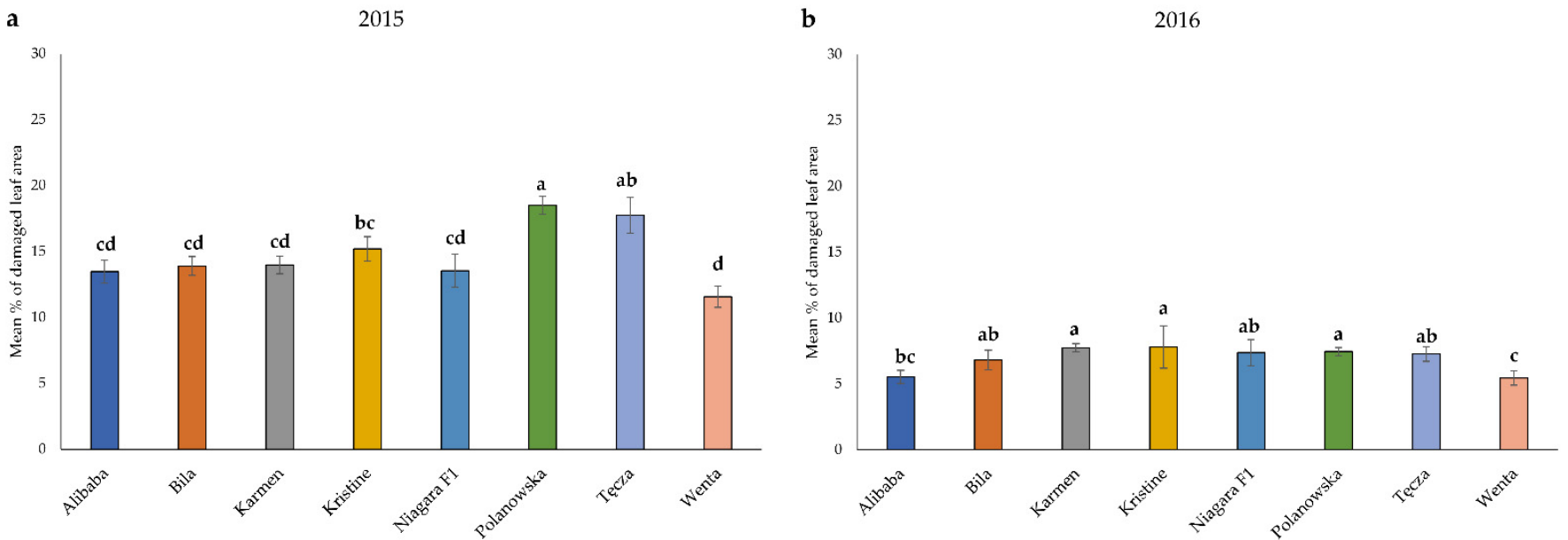

Figure 2. Mean $( \pm S E)$ percentage of the damaged leaf area caused by feeding thrips throughout the all growing season (a) in 2015 and (b) in 2016. Means with the same letters on each bar are do not differ significantly different (Duncan's multiple range Test, $p<0.05$ ).

For the year 2016, the mean number of adults onion thrips during onion plants colonization was the highest—by a significant margin —on Alibaba, Kristine, Niagara $\mathrm{F}_{1}$, and Polanowska in comparison with the least colonized (Tęcza), followed by Bila (Figure 1d). A significantly higher seasonal mean number of thrips adults and larvae throughout the whole growing season was detected on Alibaba and Niagara $F_{1}$ than on the other cultivars, except for Polanowska. Kristine and Wenta fell into the second homogenous group when Duncan's test was performed, while Bila and Tęcza fell into the third and fourth groups, respectively (Figure 1e). The larvae accounted for $26.5-47.8 \%$ of total mean thrips per 10 leaves and a significantly higher seasonal mean number of thrips larvae was detected on Alibaba and Niagara $F_{1}$ in comparison with the other cultivars (Figure 1f).

The factorial analyses indicated highly significant differences in the number of thrips sampled on the different cultivars on most of the sampling dates (Table S2). Onion thrips population density was usually significantly higher on Alibaba, Niagara $F_{1}$, and Polanowska than on Bila, Karmen, and Tęcza (Figure S4).

Significant variability of cultivars was found in terms of the mean percentage of damaged leaf area caused by feeding thrips. There was a block effect for this parameter $(p=0.049)$ (Table S1). The mean percentage of damaged leaf area was significantly the highest on Karmen, Kristine, and Polanowska in comparison to less susceptible to thrips feeding Alibaba and resistant Wenta (Figure 2b).

The factorial analyses indicated significant differences in the percentage of damaged leaf area sampled on the different cultivars on 7 July with significantly most damaged cv. Tęcza in comparison to others, and on the two last sampling dates in August with significantly the most damaged (Karmen and Polanowska) and significantly the least damaged (Alibaba and Wenta) (Figure S5, Table S2).

Based on these results, two cultivars with field resistance to thrips abundance were identified: Tęcza and Wenta, one cultivar resistant to thrips feeding: Wenta, five susceptible: Alibaba, Bila, Karmen, Kristine, and Polanowska, and one highly susceptible: Niagara $F_{1}$. All these susceptible cultivars were the most attractive to adult onion thrips for colonization, with Niagara $F_{1}$ better supporting the thrips infestation during the migration period. Two cultivars Teecza and Wenta were resistant and moderately resistant to migrating adult thrips, respectively (Table 2). 
Table 2. Level of resistance of eight onion cultivars to Thrips tabaci.

\begin{tabular}{|c|c|c|c|c|c|c|}
\hline \multirow{3}{*}{ Cultivars } & \multirow{2}{*}{\multicolumn{2}{|c|}{$\begin{array}{c}\text { Resistance to } \\
\text { Plant Colonization } \\
\text { by Migrating Adult Thrips }\end{array}$}} & \multicolumn{4}{|c|}{ Field Resistance throughout the Growing Season } \\
\hline & & & \multicolumn{2}{|c|}{$\begin{array}{c}\text { Resistance to } \\
\text { Thrips Abundance }\end{array}$} & \multicolumn{2}{|c|}{$\begin{array}{c}\text { Resistance to } \\
\text { Thrips Damage }\end{array}$} \\
\hline & $\begin{array}{l}\text { No. } \\
\text { Points }\end{array}$ & $\begin{array}{c}\text { Level of } \\
\text { Resistance }\end{array}$ & $\begin{array}{l}\text { No. } \\
\text { Points }\end{array}$ & $\begin{array}{c}\text { Level of } \\
\text { Resistance }\end{array}$ & $\begin{array}{l}\text { No. } \\
\text { Points }\end{array}$ & $\begin{array}{c}\text { Level of } \\
\text { Resistance }\end{array}$ \\
\hline Alibaba & 1.5 & susceptible & 1.5 & susceptible & 2.0 & susceptible \\
\hline Bila & 2.0 & susceptible & 2.5 & susceptible & 2.0 & susceptible \\
\hline Karmen & 1.5 & susceptible & 2.0 & susceptible & 1.5 & susceptible \\
\hline Kristine & 1.5 & susceptible & 2.5 & susceptible & 1.5 & susceptible \\
\hline Niagara $F_{1}$ & 1.0 & $\begin{array}{l}\text { high } \\
\text { susceptible }\end{array}$ & 1.0 & $\begin{array}{l}\text { high } \\
\text { susceptible }\end{array}$ & 1.5 & susceptible \\
\hline Polanowska & 1.5 & susceptible & 2.0 & susceptible & 1.0 & $\begin{array}{l}\text { high } \\
\text { susceptible }\end{array}$ \\
\hline Tęcza & 3.5 & resistant & 4.0 & resistant & 1.5 & susceptible \\
\hline Wenta & 3.0 & $\begin{array}{l}\text { Moderately } \\
\text { resistant }\end{array}$ & 2.5 & $\begin{array}{l}\text { Moderately } \\
\text { resistant }\end{array}$ & 4.0 & resistant \\
\hline
\end{tabular}

Note: the level of resistance: $>3.00$ points—resistant; 3.00-2.50 points—moderately resistant; $2.49-1.5$ pointssusceptible; $<1.5$ points-high susceptible.

\subsection{Biochemical Bases of Resistance}

In both 2015 and 2016, there was a significant effect of variety $(p<0.05)$ on the contents of soluble and reducing sugars, sucrose, and total phenolics in the undamaged leaves by feeding onion thrips of onion cultivars, and there was no block effect only on concentrations of sucrose in 2015 and total phenolics in both years (Tables 3 and 4).

In 2015, most onion cultivars differed significantly from each other in terms of contents of soluble sugars and sucrose in leaves, and only Karmen with Niagara $F_{1}$ and Bila with Kristine fall into the same homogenous groups when the Duncan test was performed (Table 3). The highest mean quantity of soluble sugars and sucrose in leaves was shown by cv. Wenta, a cultivar resistant to thrips damage, while the lowest concentrations of both carbohydrates were shown by a cultivar susceptible to thrips abundance and thrips damage, namely cv. Polanowska. The sequence of other cultivars in terms of contents of soluble sugars and sucrose was the same for both carbohydrates (Table 3). The cultivar found to be second most susceptible to thrips damage in 2015 (cv. Tẹcza) was placed at the end of the list in terms of the contents of soluble sugars and sucrose and contained carbohydrates in average concentrations compared to other cultivars (Table 3). Significantly, the highest quantity of reducing sugars was found in the leaves of the cultivars Alibaba and Niagara $F_{1}$ with a high density of thrips, but moderately damaged leaves in 2015 (Table 3). A cultivar susceptible to thrips damage (cv. Kristine) contained the lowest concentration of reducing sugars, but it did not significantly different from the quantity thereof in the leaves of Bila and Wenta, which had a lower percentage of damaged leaf area (Table 3). 
Table 3. The contents of sugars and total phenols in the not damaged by Thrips tabaci leaves of the onion cultivars in 2015, $\mathrm{df}=7$.

\begin{tabular}{ccccc}
\hline \multirow{2}{*}{ Cultivar } & \multicolumn{4}{c}{ Mean Quantity $\left( \pm\right.$ SE) $\left(\mathbf{m g} / \mathbf{1 0 0} \mathbf{g ~ F W} \mathbf{~}^{\mathbf{1}}\right)$} \\
\cline { 2 - 5 } & Soluble Sugars & Reducing Sugars & Sucrose & Total Phenols \\
\hline Alibaba & $1.25 \pm 0.012 \mathrm{~b}^{2}$ & $0.125 \pm 0.012 \mathrm{a}$ & $1.13 \pm 0.004 \mathrm{~b}$ & $97.23 \pm 1.24 \mathrm{~b}$ \\
Bila & $0.91 \pm 0.024 \mathrm{e}$ & $0.077 \pm 0.003 \mathrm{bc}$ & $0.84 \pm 0.021 \mathrm{e}$ & $72.63 \pm 0.33 \mathrm{~d}$ \\
Karmen & $1.13 \pm 0.002 \mathrm{c}$ & $0.084 \pm 0.001 \mathrm{~b}$ & $1.04 \pm 0.002 \mathrm{c}$ & $74.85 \pm 0.15 \mathrm{~d}$ \\
Kristine & $0.91 \pm 0.002 \mathrm{e}$ & $0.067 \pm 0.007 \mathrm{c}$ & $0.85 \pm 0.002 \mathrm{e}$ & $64.75 \pm 0.88 \mathrm{~d}$ \\
Niagara F & $1.15 \pm 0.002 \mathrm{c}$ & $0.124 \pm 0.008 \mathrm{a}$ & $1.02 \pm 0.006 \mathrm{c}$ & $81.50 \pm 0.62 \mathrm{c}$ \\
Polanowska & $0.86 \pm 0.007 \mathrm{f}$ & $0.074 \pm 0.001 \mathrm{bc}$ & $0.78 \pm 0.006 \mathrm{f}$ & $73.24 \pm 0.43 \mathrm{~d}$ \\
Tęcza & $1.05 \pm 0.007 \mathrm{~d}$ & $0.079 \pm 0.002 \mathrm{~b}$ & $0.97 \pm 0.005 \mathrm{~d}$ & $68.08 \pm 0.85 \mathrm{~d}$ \\
Wenta & $1.35 \pm 0.008 \mathrm{a}$ & $0.077 \pm 0.006 \mathrm{bc}$ & $1.27 \pm 0.004 \mathrm{a}$ & $99.93 \pm 1.37 \mathrm{a}$ \\
$p$ cultivar & $<0.001$ & $<0.001$ & $<0.001$ & $<0.001$ \\
F blocks & 8.6 & 11.657 & 1.9 & 0.58 \\
$p$ blocks & $<0.001$ & $<0.001$ & 0.156 & 0.636 \\
\hline
\end{tabular}

Note: ${ }^{1} \mathrm{FW}=$ Fresh weight; ${ }^{2}$ means within a column followed by the same letter(s) do not differ significantly (Duncan's Multiple Range Test $p<0.05$ ).

Table 4. The contents of sugars and total phenols in the not damaged by Thrips tabaci leaves of the tested onion cultivars in 2016, $\mathrm{df}=7$.

\begin{tabular}{ccccc}
\hline \multirow{2}{*}{ Cultivar } & \multicolumn{3}{c}{ Mean Quantity $( \pm \mathbf{S E}) \mathbf{( m g / 1 0 0 ~ g ~ \text { FW } ^ { \mathbf { 1 } } )}$} \\
\cline { 2 - 5 } & Soluble Sugars & Reducing Sugars & Sucrose & Total Phenols \\
\hline Alibaba & $1.17 \pm 0.011 \mathrm{~b}^{2}$ & $0.13 \pm 0.001 \mathrm{a}$ & $1.04 \pm 0.010 \mathrm{c}$ & $74.82 \pm 1.23 \mathrm{a}$ \\
Bila & $0.96 \pm 0.009 \mathrm{f}$ & $0.10 \pm 0.001 \mathrm{c}$ & $0.87 \pm 0.008 \mathrm{f}$ & $54.83 \pm 0.27 \mathrm{~d}$ \\
Karmen & $1.19 \pm 0.016 \mathrm{~b}$ & $0.09 \pm 0.003 \mathrm{~d}$ & $1.10 \pm 0.014 \mathrm{~b}$ & $57.92 \pm 0.30 \mathrm{c}$ \\
Kristine & $0.94 \pm 0.028 \mathrm{f}$ & $0.05 \pm 0.004 \mathrm{f}$ & $0.88 \pm 0.024 \mathrm{f}$ & $47.91 \pm 0.54 \mathrm{~d}$ \\
Niagara $\mathrm{F}_{1}$ & $1.09 \pm 0.010 \mathrm{c}$ & $0.11 \pm 0.001 \mathrm{~b}$ & $0.97 \pm 0.009 \mathrm{~d}$ & $67.55 \pm 0.68 \mathrm{~b}$ \\
Polanowska & $1.37 \pm 0.014 \mathrm{a}$ & $0.12 \pm 0.002 \mathrm{~b}$ & $1.25 \pm 0.013 \mathrm{a}$ & $49.69 \pm 0.70 \mathrm{~d}$ \\
Tęcza & $1.03 \pm 0.08 \mathrm{~d}$ & $0.10 \pm 0.001 \mathrm{c}$ & $0.93 \pm 0.007 \mathrm{e}$ & $76.26 \pm 0.69 \mathrm{a}$ \\
Wenta & $1.09 \pm 0.019 \mathrm{e}$ & $0.08 \pm 0.003 \mathrm{e}$ & $0.92 \pm 0.016 \mathrm{e}$ & $75.86 \pm 1.87 \mathrm{a}$ \\
$p$ cultivar & $<0.001$ & $<0.001$ & $<0.001$ & $<0.001$ \\
F blocks & 16.3 & 9.12 & 15.5 & 0.77 \\
$p$ blocks & $<0.001$ & $<0.001$ & 0.005 & 0.523 \\
\hline
\end{tabular}

Note: ${ }^{1} \mathrm{FW}=$ Fresh weight; ${ }^{2}$ means within a column followed by the same letter(s) do not differ significantly (Duncan's Multiple Range Test $p<0.05$ ).

For the total phenolic contents, Duncan's test produced four homogenous groups (Table 3). Cv. Wenta, which was resistant to thrips abundance and thrips damage in 2015, had the highest mean quantity of total phenolics. Cultivars Alibaba and Niagara $F_{1}$ fell into the second and third group, respectively, while the five other cultivars formed the fourth group, with the lowest quantity of total phenolics in leaves of cv. Kristine (Table 3).

In 2016, in contrast to the previous year, one of the cultivars most infested and damaged by onion thrips (cv. Polanowska) showed the highest mean quantity of soluble sugars and sucrose, while the lowest concentrations of these carbohydrates were shown by a cultivar susceptible especially to thrips damage (cv. Kristine), followed by cv. Bila (Table 4). The highest level of reducing sugars was shown by a cultivar mainly susceptible to thrips abundance (cv. Alibaba) and then two cultivars susceptible to thrips abundance and damage, namely, Niagara $F_{1}$ and Polanowska, while the lowest was detected in the leaves of Wenta (Table 4).

In 2016, the significantly highest phenolic content was found in the leaves of Tęcza, Alibaba, and Wenta, and these cultivars were characterized by high, medium, and low degrees of leaf damage, respectively. The lowest concentrations of these chemical compounds were detected in the leaves of cultivars susceptible to thrips damage, i.e., Bila, Kristine, and Polanowska (Table 4). 
In 2015, the content of reducing sugars in the undamaged leaves of onion cultivars was positively correlated with the mean number of thrips on 28 July (when the leaves were sampled for biochemical analyses) and with the seasonal mean number of thrips. In turn, the concentrations of total soluble sugars, sucrose, and total phenolics correlated negatively with the seasonal mean percentage of damaged leaf area (Table 5).

Table 5. Pearson's correlation between biochemical characteristics of onion leaves and the number of Thrips tabaci and percentage of damaged leaf area of onion leaves in $2015(n=32)$.

\begin{tabular}{|c|c|c|c|c|c|c|c|c|}
\hline \multirow{3}{*}{ Parameters } & \multicolumn{4}{|c|}{ No. of Thrips (Imago + Larvae) } & \multicolumn{4}{|c|}{ Damaged Leaf Area } \\
\hline & \multicolumn{2}{|c|}{$\begin{array}{c}\text { Mean No. of } \\
\text { Thrips on } 28 \text { July }\end{array}$} & \multicolumn{2}{|c|}{$\begin{array}{l}\text { Seasonal Mean } \\
\text { No. of Thrips }\end{array}$} & \multicolumn{2}{|c|}{$\begin{array}{c}\text { Mean Percentage of } \\
\text { Damaged Leaf Area } \\
\text { on } 28 \text { July }\end{array}$} & \multicolumn{2}{|c|}{$\begin{array}{c}\text { Seasonal Mean } \\
\text { Percentage of } \\
\text { Damaged Leaf Area }\end{array}$} \\
\hline & $\mathbf{r}$ & $p$ & $\mathbf{r}$ & $p$ & $\mathbf{r}$ & $p$ & $\mathbf{r}$ & $p$ \\
\hline $\begin{array}{c}\text { Mean quantity of total } \\
\text { soluble sugars } \\
\left(\mathrm{g} / 100^{-1} \mathrm{~g} \mathrm{FW}\right)\end{array}$ & 0.026 & 0.146 & 0.115 & 0.530 & -0.305 & 0.089 & $-0.589 *$ & 0.000 \\
\hline $\begin{array}{l}\text { Mean quantity of reducing } \\
\text { sugars }\left(\mathrm{g} / 100^{-1} \mathrm{~g} \mathrm{FW}\right)\end{array}$ & $0.579^{*}$ & 0.001 & $0.489 *$ & 0.004 & -0.216 & 0.234 & -0.281 & 0.120 \\
\hline $\begin{array}{l}\text { Mean quantity of sucrose } \\
\left(\mathrm{g} / 100^{-1} \mathrm{~g} \mathrm{FW}\right)\end{array}$ & 0.194 & 0.287 & 0.051 & 0.785 & -0.293 & 0.104 & $-0.586^{*}$ & 0.000 \\
\hline $\begin{array}{l}\text { Mean total phenols } \\
\text { contents } \\
\left(\mathrm{mg} / 100^{-1} \mathrm{~g} \mathrm{FW}\right)\end{array}$ & 0.313 & 0.081 & 0.082 & 0.655 & -0.253 & 0.162 & $-0.534^{*}$ & 0.002 \\
\hline
\end{tabular}

Note: * significant correlation at $p<0.05$.

For the year 2016, the correlation coefficient indicated that there was a positive correlation between three carbohydrates and the mean number of thrips on 8 August (when the leaves were sampled for biochemical analyses) and between the level of reducing sugars and the seasonal mean number of thrips. On the contrary, a negative significant correlation was detected between the concentration of total phenols and the mean percentage of damaged leaf area on 8 August and throughout the whole growing season (Table 6).

Table 6. Pearson's correlation between biochemical characteristics of onion leaves and the number of Thrips tabaci and percentage of damaged leaf area of onion leaves in $2016(n=32)$.

\begin{tabular}{|c|c|c|c|c|c|c|c|c|}
\hline \multirow{3}{*}{ Parameters } & \multicolumn{4}{|c|}{ No. of Thrips (Imago + Larvae) } & \multicolumn{4}{|c|}{ Damaged Leaf Area } \\
\hline & \multicolumn{2}{|c|}{$\begin{array}{c}\text { Mean No. of } \\
\text { Thrips on } 8 \text { August }\end{array}$} & \multicolumn{2}{|c|}{$\begin{array}{l}\text { Seasonal Mean } \\
\text { No. of Thrips }\end{array}$} & \multicolumn{2}{|c|}{$\begin{array}{c}\text { Mean Percentage of } \\
\text { Damaged Leaf Area } \\
\text { on } 8 \text { August }\end{array}$} & \multicolumn{2}{|c|}{$\begin{array}{c}\text { Seasonal Mean } \\
\text { Percentage of } \\
\text { Damaged Leaf Area }\end{array}$} \\
\hline & $\mathbf{r}$ & $p$ & $\mathbf{r}$ & $p$ & $\mathbf{r}$ & $p$ & $\mathbf{r}$ & $p$ \\
\hline $\begin{array}{l}\text { Mean quantity of total sugars } \\
\qquad\left(\mathrm{g} / 100^{-1} \mathrm{~g} \text { FW }\right)\end{array}$ & $0.523 *$ & 0.002 & 0.319 & 0.075 & 0.081 & 0.655 & 0.598 & 0.745 \\
\hline $\begin{array}{l}\text { Mean quantity of reducing sugars } \\
\qquad\left(\mathrm{g} / 100^{-1} \mathrm{~g} \mathrm{FW}\right)\end{array}$ & $0.395 *$ & 0.025 & $0.397 *$ & 0.024 & -0.120 & 0.513 & -0.246 & 0.175 \\
\hline $\begin{array}{c}\text { Mean quantity of sucrose } \\
\left(\mathrm{g} / 100^{-1} \mathrm{~g} \text { FW }\right)\end{array}$ & $0.508 *$ & 0.003 & 0.282 & 0.118 & 0.112 & 0.543 & 0.110 & 0.548 \\
\hline $\begin{array}{l}\text { Mean total phenols contents } \\
\left(\mathrm{mg} / 100^{-1} \mathrm{~g} \mathrm{FW}\right)\end{array}$ & -0.124 & 0.500 & 0.411 & 0.823 & $-0.390 *$ & 0.027 & $-0.421 *$ & 0.016 \\
\hline
\end{tabular}

Note: * significant correlation at $p<0.05$.

\subsection{Anatomical Characters of Leaves}

In the onion cultivars examined in 2016, the leaf blade thickness was a significantly varying trait (Table 7). It was found that cultivars Alibaba and Karmen had the thickest leaf blades, while the thinnest leaf blades were found for Polanowska, followed by Wenta (Table 7). 
Table 7. Leaf blade thickness of the tested Alium cepa cultivars in 2016, $\mathrm{df}=7$.

\begin{tabular}{cccc}
\hline Cultivar & $\begin{array}{c}\text { Max. Leaf Blade } \\
\text { Thickness } \\
\text { (Mean } \pm \text { SE) }(\boldsymbol{\mu m})\end{array}$ & $\begin{array}{c}\text { Min. Leaf Blade } \\
\text { Thickness } \\
\text { (Mean } \pm \text { SE) }(\boldsymbol{\mu m})\end{array}$ & $\begin{array}{c}\text { Mean Leaf Blade } \\
\text { Thickness } \\
\text { (Mean } \pm \text { SE) }(\boldsymbol{\mu m})\end{array}$ \\
\hline Alibaba & $528.6 \pm 6.84 \mathrm{c}^{1}$ & $520.6 \pm 6.86 \mathrm{a}$ & $524.6 \pm 6.74 \mathrm{a}$ \\
Bila & $495.4 \pm 2.73 \mathrm{~d}$ & $347.0 \pm 5.63 \mathrm{e}$ & $421.2 \pm 2.73 \mathrm{~d}$ \\
Karmen & $598.4 \pm 5.71 \mathrm{a}$ & $432.0 \pm 3.66 \mathrm{~b}$ & $515.2 \pm 2.72 \mathrm{a}$ \\
Kristine & $566.0 \pm 7.44 \mathrm{~b}$ & $409.6 \pm 27.51 \mathrm{bc}$ & $487.8 \pm 17.24 \mathrm{~b}$ \\
Niagara F & $451.6 \pm 3.53 \mathrm{e}$ & $376.4 \pm 5.45 \mathrm{~cd}$ & $414.0 \pm 2.24 \mathrm{~d}$ \\
Polanowska & $385.0 \pm 4.37 \mathrm{~g}$ & $367.2 \pm 2.17 \mathrm{de}$ & $376.1 \pm 2.35 \mathrm{f}$ \\
Tęcza & $503.8 \pm 3.55 \mathrm{~d}$ & $403.6 \pm 4.74 \mathrm{bc}$ & $453.7 \pm 2.78 \mathrm{c}$ \\
Wenta & $435.2 \pm 3.68 \mathrm{f}$ & $357.8 \pm 4.29 \mathrm{de}$ & $396.5 \pm 2.21 \mathrm{e}$ \\
F cultivar & 217.00 & 25.3 & 77.0 \\
$p$ cultivar & $<0.001$ & $<0.001$ & $<0.001$ \\
\hline
\end{tabular}

Note: ${ }^{1}$ means within a column followed by the same letter(s) do not differ significantly (Duncan's Multiple Range Test $p<0.05)$.

The thickness of the epidermis, perimeter, and area of the epidermal cells, as well as mesophyll cells were significantly affected by onion cultivars $(p<0.05)$ (Table 8$)$.

Table 8. The evaluated parameters of the leaf's epidermal and mesophyll cells in evaluated eight different Allium cepa cultivars in 2016, $\mathrm{df}=7$.

\begin{tabular}{|c|c|c|c|c|c|c|}
\hline \multirow[b]{3}{*}{ Cultivar } & \multicolumn{3}{|c|}{ Epidermis } & \multicolumn{3}{|c|}{ Mesophyll } \\
\hline & \multicolumn{3}{|c|}{ Mean $( \pm$ SE) } & \multirow[b]{2}{*}{$\begin{array}{l}\text { Cell Layers } \\
\text { (No) }\end{array}$} & \multicolumn{2}{|c|}{ Mean $( \pm$ SE) } \\
\hline & $\begin{array}{l}\text { Thickness } \\
\qquad(\mu \mathrm{m})\end{array}$ & $\begin{array}{l}\text { Perimeter } \\
\quad(\mu \mathrm{m})\end{array}$ & $\begin{array}{c}\text { Area }( \pm S E) \\
\left(\mu \mathrm{m}^{2}\right)\end{array}$ & & $\begin{array}{l}\text { Perimeter } \\
(\mu \mathrm{m})\end{array}$ & $\begin{array}{c}\text { Area } \\
\left(\mu \mathrm{m}^{2}\right)\end{array}$ \\
\hline Alibaba & $25.65 \pm 0.96 b^{1}$ & $84.23 \pm 9.70 c$ & $482.06 \pm 26.26 \mathrm{c}$ & 7 & $115.98 \pm 10.51 \mathrm{e}$ & $734.04 \pm 131.19 \mathrm{~d}$ \\
\hline Bila & $27.38 \pm 0.79 \mathrm{ab}$ & $100.33 \pm 15.01 \mathrm{ab}$ & $654.24 \pm 35.99 \mathrm{ab}$ & 8 & $208.85 \pm 12.39 \mathrm{a}$ & $1579.52 \pm 151.44 \mathrm{abc}$ \\
\hline Karmen & $27.61 \pm 1.07 \mathrm{ab}$ & $96.50 \pm 18.58 b$ & $615.49 \pm 43.88 b c$ & 7 & $194.89 \pm 9.19 \mathrm{ab}$ & $1652.59 \pm 116.56 \mathrm{a}$ \\
\hline Kristine & $29.95 \pm 0.65 a$ & $107.78 \pm 9.22 \mathrm{a}$ & $775.38 \pm 26.19 \mathrm{a}$ & 6 & $192.20 \pm 14.23 \mathrm{abc}$ & $1780.38 \pm 198.65 \mathrm{ab}$ \\
\hline Niagara $F_{1}$ & $26.280 .97 \mathrm{~b}$ & $93.77 \pm 11.26 b$ & $568.00 \pm 31.80 \mathrm{bc}$ & 6 & $152.49 \pm 15.42$ cde & $1121.54 \pm 168.21 \mathrm{bc}$ \\
\hline Polanowska & $26.08 \pm 1.56 b$ & $108.15 \pm 18.40 \mathrm{a}$ & $789.77 \pm 68.38 \mathrm{a}$ & 7 & $140.02 \pm 15.94 \mathrm{~cd}$ & $1084.48 \pm 171.63 \mathrm{~cd}$ \\
\hline Tęcza & $25.38 \pm 1.01 \mathrm{~b}$ & $99.88 \pm 18.50 \mathrm{ab}$ & $687.90 \pm 52.03 \mathrm{ab}$ & 6 & $166.41 \pm 11.31 \mathrm{abcd}$ & $1480.72 \pm 156.18 \mathrm{abc}$ \\
\hline Wenta & $24.28 \pm 1.10 \mathrm{~b}$ & $95.23 \pm 17.20 \mathrm{~b}$ & $594.28 \pm 46.91 \mathrm{bc}$ & 8 & $153.72 \pm 11.10 \mathrm{bcd}$ & $1142.13 \pm 140.64 \mathrm{abc}$ \\
\hline F cultivar & 3.17 & 4.70 & 4.71 & & 4.88 & 4.34 \\
\hline$p$ cultivar & 0.004 & $<0.001$ & $<0.001$ & & $<0.001$ & $<0.001$ \\
\hline
\end{tabular}

Note: ${ }^{1}$ means within a column followed by the same letter(s) do not differ significantly (Duncan's Multiple Range Test $p<0.05)$.

For the thickness of the epidermis, Duncan's test gave two homogenous groups. Cv. Kristine, which was the most damaged by onion thrips in 2016, had the thickest epidermis layer and fell into the first group, while three cultivars susceptible to thrips damage, namely Niagara $F_{1}$, Polanowska, Tẹcza as well as moderately resistant Alibaba and resistant Wenta, were placed into the second group. The mean thickness of the epidermis of two susceptible cultivars Bila and Karmen did not differ significantly from other cultivars (Table 8, Figure 2b). The leaf blades of Alibaba, Karmen, and Wenta were characterized by the smallest perimeter and area of epidermal cells in comparison with Kristine and Polanowska (differing significantly). Alibaba also showed smaller mesophyll cells in comparison to other onion cultivars; their perimeter and area proved to be significantly smaller than in other cultivars, except for the area of the mesophyll cells of cv. Polanowska (Table 8). Analyzed material had a similar number of cell layers in the mesophyll (about 6-8 layers). A leaf anatomical study revealed that vascular bundles (VB) were arranged in one row. There was a cultivar effect only on the mean distance between them and the largest values were noted between VB of Alibaba in comparison to others, except for Bila and Karmen (Table 9). The smallest distance between VB was detected in the leaves of Polanowska but it did not differ statistically from that of Kristine, Niagara $F_{1}$, Tęcza, and Wenta (Table 9). Despite the lack of significant differences between the mean diameter, perimeter, and cross-sectional area of vascular bundles of the tested onion cultivars, the 
smallest mean perimeter and mean cross-sectional area were found in the leaves of cv. Wenta, which was the least damaged by thrips in 2016, while the largest was found in Bila and Karmen, which were highly damaged by these pests (Table 9).

Table 9. The evaluated parameters of vascular bundles (VB) in leaves of evaluated eight different Allium cepa cultivars in 2016, $\mathrm{df}=7$.

\begin{tabular}{|c|c|c|c|c|}
\hline Cultivar & $\begin{array}{l}\text { Mean Diameter } \\
\quad( \pm S E)(\mu \mathrm{m})\end{array}$ & $\begin{array}{l}\text { Mean Perimeter }( \pm \mathrm{SE}) \\
(\mu \mathrm{m})\end{array}$ & $\begin{array}{c}\text { Mean Cross-Section } \\
\text { Area } \\
( \pm \mathrm{SE})\left(\mu \mathrm{m}^{2}\right)\end{array}$ & $\begin{array}{c}\text { Mean Distance } \\
\text { Between VB } \\
( \pm S E)(\mu \mathrm{m})\end{array}$ \\
\hline Alibaba & $156.67 \pm 9.95$ & $478.00 \pm 12.16$ & $13,077.33 \pm 418.41$ & $>1000.00 \mathrm{a}^{1}$ \\
\hline Bila & $118.33 \pm 19.01$ & $594.67 \pm 101.13$ & $17,144.00 \pm 5637.38$ & $831.68 \pm 88.52 \mathrm{ab}$ \\
\hline Karmen & $170.00 \pm 57.41$ & $504.00 \pm 153.13$ & $16,817.67 \pm 7145.38$ & $744.33 \pm 128.19 \mathrm{abc}$ \\
\hline Kristine & $154.67 \pm 40.68$ & $470.00 \pm 103.92$ & $12,752.00 \pm 3995.18$ & $438.00 \pm 22.19 \mathrm{bcd}$ \\
\hline Niagara $F_{1}$ & $53.00 \pm 3.51$ & $289.00 \pm 46.36$ & $4836.67 \pm 1573.59$ & $347.67 \pm 10.82 \mathrm{~cd}$ \\
\hline Polanowska & $76.67 \pm 12.17$ & $241.00 \pm 30.80$ & $3936.00 \pm 1000.16$ & $264.33 \pm 65.46 \mathrm{~d}$ \\
\hline Tęcza & $116.67 \pm 52.44$ & $343.66 \pm 134.55$ & $7752.33 \pm 5078.374$ & $496.00 \pm 252.68 \mathrm{~cd}$ \\
\hline Wenta & $60.00 \pm 19.03$ & $212.67 \pm 68.91$ & $3059.33 \pm 1945.752$ & $454.00 \pm 112.01 \mathrm{bcd}$ \\
\hline F cultivar & 2.191 & 2.146 & 2.164 & 4.587 \\
\hline$p$ cultivar & 0.092 & 0.098 & 0.095 & 0.005 \\
\hline
\end{tabular}

Note: ${ }^{1}$ means within a column followed by the same letter(s) do not differ significantly (Duncan's Multiple Range Test $p<0.05)$.

The phloem part of the vascular bundles was oriented to the upper leaf surface. Therefore, it is of significance how deeply the collateral bundles lie in the leaf mesophyll and this feature is directly related to the thickness of the leaf blade. The leaf blades lacked a clear palisade mesophyll evolved secondarily from spongy ones.

The correlation coefficient of anatomical parameters of onion leaves indicated that there was a significant correlation among the three variables. To simplify the coverage of the results, the significant correlations are included in the main text while the results of all computed interactions are included in Table S3. The mean area of mesophyll cells correlated negatively with the seasonal mean number of thrips $(r=-0.734, p=0.038)$, as well as the mean perimeter of vascular bundles with the seasonal mean number of thrips and the mean number of thrips observed on plants 8 August $(r=-0.710, p=0.048)$, when onion leaves were sampled for anatomical studies. On the contrary, the mean area of mesophyll cells was positively correlated with an increasing percentage of damaged leaf area detected on 8 August $(r=0.738, p=0.036)$.

\subsection{Effect of Mechanical Injury Caused by Feeding Onion Thrips on the Concentration of Carbohydrates, Total Phenolics, and Leaf Pigments Contents in Onion Leaves}

Total soluble sugars, reducing sugars, sucrose, and total phenolic contents in the undamaged onion leaves in 2015 and 2016 are presented in Tables 3 and 4, respectively, while in damaged leaves by feeding thrips is shown in Tables S4 and S5. In both years, there was a significant effect of the cultivar $(p<0.05)$ on contents of soluble and reducing sugars, sucrose, and total phenolics in the damaged leaves of onion cultivars, and there was no block effect on concentrations of sucrose and total phenolics in 2015 and total phenolics in 2016 (Tables S4 and S5).

Chlorophyll $\mathrm{a}$ and $\mathrm{b}$ and total carotenoid contents in undamaged and damaged onion leaves are presented in Tables S6 and S7. In both years, there was a significant effect of the variety $(p<0.05)$ on contents of chlorophyll $\mathrm{a}$ and $\mathrm{b}$, and sum of carotenoids in undamaged and damaged leaves of onion cultivars, and there was no block effect only on concentrations of chlorophyll b and a sum of carotenoids in damaged leaves in 2015 (Tables S6 and S7).

Two-way ANOVA analysis showed significant differentiation in the size of cultivar and damage level in terms of the analyzed biochemical parameters of onion leaves (Table S8). 
In the leaves of onion plants which were not damaged by the onion thrips, the contents of total soluble sugars and sucrose were significantly higher than in damaged leaves in all onion cultivars, in both 2015 and 2016 (Figure 3a,c,e,g).

The highest decrease in the concentration of soluble sugars and sucrose $(>20 \%)$ was recorded for Alibaba, Karmen, and Wenta in 2015 (Figure 3a) and Kristine and Niagara $\mathrm{F}_{1}$ in 2016 (Figure 3e), while the smallest decrease was observed $(<10.3 \%)$ for Bila and Kristine in 2015 (Figure 3a). Furthermore, a high decrease in sucrose concentration (>20\%) was observed in the leaves of Polanowska and Niagara $F_{1}$ in 2015 (Figure 3c). In 2015, Alibaba, Karmen, and Niagara $F_{1}$ did not respond to the feeding of the onion thrips with significant changes in the concentration of reducing sugars (Figure 1b). In that year, thrips caused the highest significant increase in the concentrations of reducing sugars in damaged leaves of Wenta (>50\%) and Bila, Tęcza, Kristine, and Polanowska (from $15.33 \%$ to $25.56 \%$ ) (Figure 3b). In 2016, Tęcza responded to the feeding of the thrips with a significant increase in the concentration of reducing sugars, while in the case of the Bila and Wenta opposite responses were recorded (Figure 3f).

The concentrations of total phenolics in leaves damaged by feeding onion thrips were significantly higher than in undamaged leaves in all onion cultivars in 2015, and-in the case of Bila, Karmen, Polanowska, Tęcza, and Wenta-also in 2016. All of these cultivars, except for Niagara $F_{1}$ and Polanowska in 2015, reacted to thrips feeding with an increase in the of total phenols contents above $10 \%$ (Figure $3 \mathrm{~d}, \mathrm{~h}$ ).

In 2015, all onion cultivars responded to the feeding of onion thrips with a decrease in the contents of all tested leaf pigments, but this result was significant only in the case of five onion cultivars: Bila, Karmen, Kristine, Polanowska, and Tęcza in terms of chlorophyll a; three cultivars; Kristine, Niagara $\mathrm{F}_{1}$, and Wenta in terms of chlorophyll b; and two cultivars: Bila and Wenta in terms of total carotenoids. The highest decrease, of more than $10 \%$, was observed for the content of chlorophyll b (Figure $4 a-c)$.

In 2016, thrips feeding caused a significant decrease in the concentrations of chlorophyll $\mathrm{a}$ and $\mathrm{b}$ and total carotenoids in leaves of all onion cultivars with the exception of chlorophyll $\mathrm{b}$ in the case of Polanowska. The highest reduction of all leaf pigments (>20\%) was detected in the leaves of cv. Tęcza (Figure $4 \mathrm{~d}-\mathrm{f}$ ). 

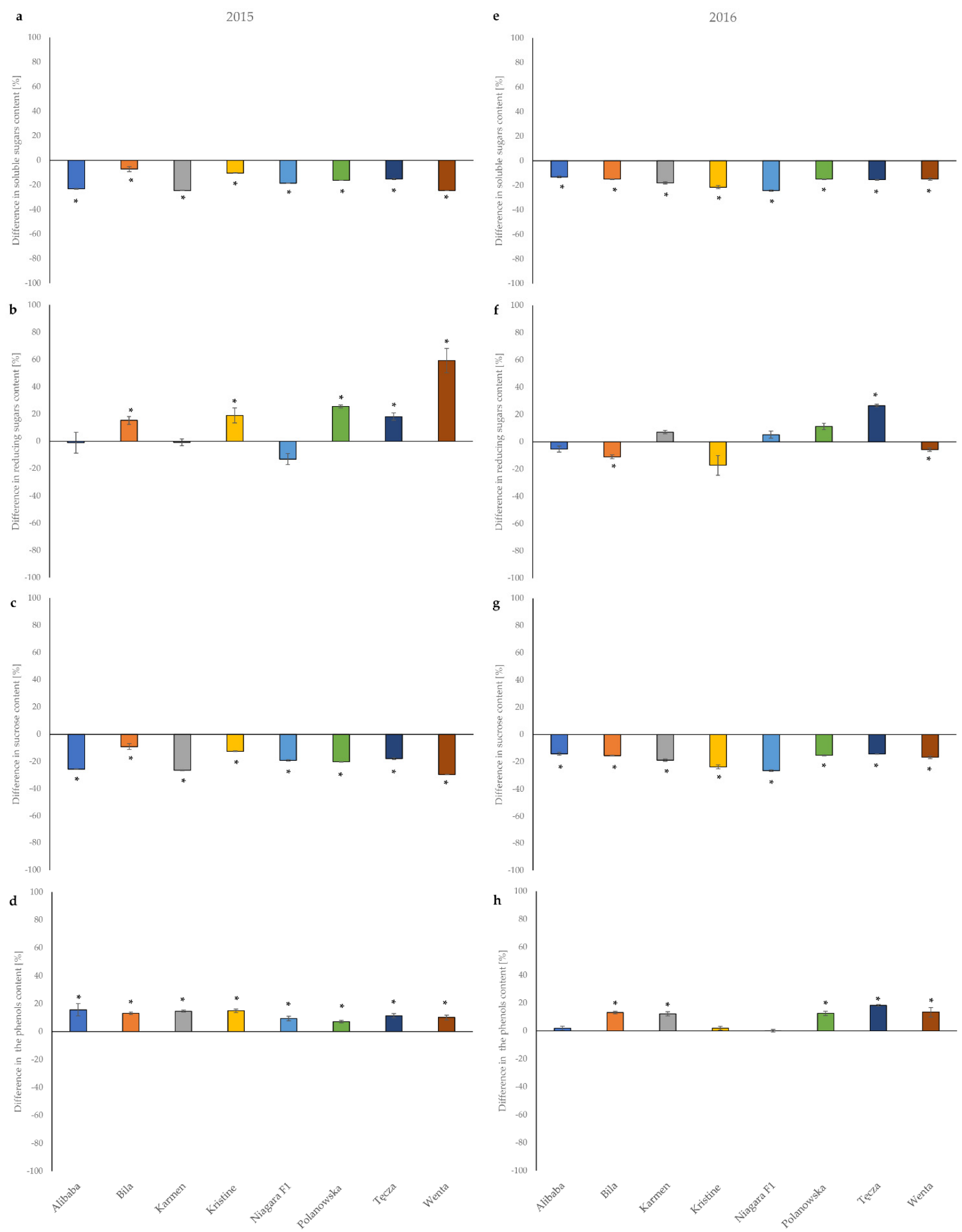

Figure 3. Effects of Thrips tabaci foraging on contents of (a,e) soluble sugars, $(\mathbf{b}, \mathbf{f})$ reducing sugars, $(\mathbf{c}, \mathbf{g})$ sucrose, $(\mathbf{d}, \mathbf{h})$ total phenols in the leaves of tested onion cultivars in 2015 and 2016. * significant differences between the control mean and the mean in colonized plants based on the Student's $t$-test conducted separately for each cultivar $(p<0.05)$. 

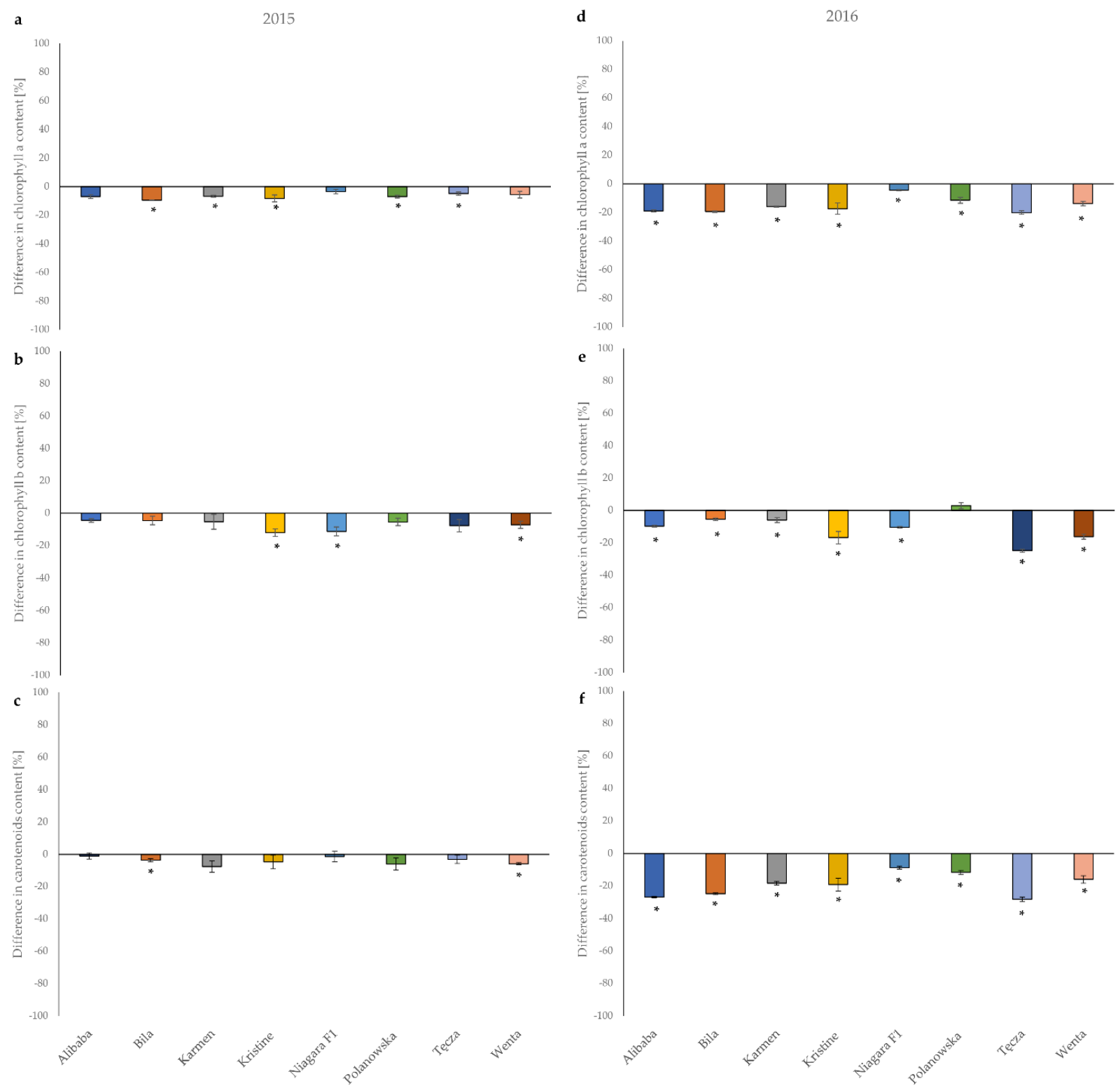

Figure 4. Effects of Thrips tabaci foraging on contents of $(\mathbf{a}, \mathbf{d})$ chlorophyll $\mathbf{a},(\mathbf{b}, \mathbf{e})$ chlorophyll b, and $(\mathbf{c}, \mathbf{f})$ carotenoids in the leaves of tested onion cultivars in 2015 and 2016. * significant differences between the control mean and the mean in colonized plants based on the Student's $t$-test conducted separately for each cultivar $(p<0.05)$.

\section{Discussion}

In the field experiment, two cultivars Tęcza and Wenta were moderately resistant and resistant, respectively, to onion thrips as reflected in the lower thrips population and/or low percentage of damaged leaf area by feeding thrips observed throughout the growing season. Nevertheless, because the experiment involved both mechanisms (antixenosis, antibiosis), attempts to apportion one (or both) of those mechanisms as the factor contributing most significantly to the observed difference in the level of overall pest resistance are inherently difficult. Antixenosis testing is mainly based on measuring the attractiveness of a plant genotype to colonizers and is an important component of resistance because it reduces the initial infestation level [52]. In our experiment, the weak colonization of cultivars Tęcza and Wenta by migrating adult thrips may indicate host plant selection and the antixenotic (no preference) mechanism of resistance of these cultivars. Antixenosis has been documented in onion and cabbage for onion thrips and some of the plant characteristics that 
are perceivable before landings, such as the size, shape, and scent of the host plant, as well as colour and light reflectance of leaves have been involved in this mechanism [26-28,53,54]. Moreover, differences in foliar reflectance of light could be due to differences in profiles of cuticular waxes between resistant and susceptible cultivars [13,26,37]. As mentioned in the introduction, onion cultivars with glossy and light yellow-green foliage support a lower number of onion thrips and suffer less feeding damage in comparison with nonglossy (waxy) and blue-green susceptible cultivars [26,36]. However, a lighter leaf colour of onion accessions and/or a lesser amount of epicuticular wax did not always result in the fewest number of thrips per plant [55]. It is supposed that a decreased amount of cuticular wax in resistant onion varieties suppresses thrips feeding on leaves to a greater degree than onion colonization by them because the wax layer allows them to adhere to the plant and cause damage [36,55]. On the contrary, Eigenbrode et al. [56] found that on cabbage leaves, a high quantity of wax hinders the movement of small insects probably by means of wax crystals accumulating on the tarsae. A negative relationship between the amount of epicuticular waxes and the densities of thrips and damage caused by them in cabbage plants was reported by Trdan et al. [57] and Voorrips et al. [58]. In our study, onion cultivars resistant to migrating thrips settlement (Wenta and Tecza) stood out among other varieties due to their darker, green-grey-yellowish leaf color, while susceptible cultivars had the vivid, intense green-yellowish color of chives [42]. Colour characteristics of leaves of tested onion cultivars have been described in detail in the earlier work of Pobożniak et al. [42], while the amount and composition of the epicuticular wax have not been identified so far.

The lower values of thrips abundance obtained from field tests on the cultivars Tęcza and Wenta throughout both growing seasons and cultivars Kristine in 2015 and Bila and Karmen in 2016 indicate that the onion thrips population did not reach a high abundance, which could be due to them not being able to successfully build up large populations on these cultivars under natural conditions, which may have resulted from antixenosis during pre-foraging and/or antibiosis during feeding. Field screening of onion cultivars revealed also differences in plant injury caused by thrips feeding between tested cultivars. According to Lewis [59], the method of feeding and the shape and depth of damage left by thrips vary between resistant and susceptible plants. Mollema et al. [60] found that on susceptible varieties of cucumber, the feeding holes caused by western flower thrips, Frankliniella occidentalis Pergande were grouped while on resistant varieties, thrips appeared restless, spent most of their time walking, and the feeding holes were scattered individually. In both years of our study, fewer and scattered traces of foraging by onion thrips were observed on the leaves of cv. Wenta, although this cultivar was subject to the pressure of a similar pest population as the more extensively damaged cultivars Kristine and Polanowska. In turn, cv. Tęcza possessed fewer thrips per plant than other cultivars, but a percentage of the damaged leaf area on it was comparable to those on cultivars susceptible to thrips damage like Polanowska (in both years) and Niagara $F_{1}$, Karmen, and Kristine in 2016. Njau et al. [40] also observed negative (although non-significant) correlations between the number of onion thrips and the mean leaf damage in different onion accessions; Miyazaki et al. [61] reported similar findings in the case of onion thrips, western flower thrips, and cotton thrips, Frankliniella schultzei (Trybom) on cotton cultivars. The similarities in the levels of thrips damage among cultivars harboring a different number of thrips, as vividly exemplified by Tęcza and Polanowska, suggest that the resistance to thrips damage and the abundance could be linked to the different specific traits of the onion cultivars.

Primary metabolites such as proteins and carbohydrates are nutrients needed to synthesize body tissue and serve as energy sources, stimulating feeding, and influencing life-history parameters of thrips [29,62]. In studies by Agbahoungba et al. [63], the concentration of total sugars and reducing sugars in the plants of cowpea contributed to the reduction of damage caused by flower bud thrips, Megalurothrips sjostedti Trybom. Contradictory findings have been reported by Kandakoor et al. [64] and Chandrayudu et al. [65], who found a positive relationship between the quantity of total sugars and the number of thrips on peanuts. Similarly, Njau et al. [40] and Bhonde et al. [66] found 
that the total sugars content in leaves of onion accessions was positively correlated with the number of onion thrips, while the authors also reported an inverse (although nonsignificant) relationship between their concentration and thrips damage. Pobożniak and Koschier [30] and Žnidarčič et al. [67] proved that sucrose contents in the leaves promoted the population growth of the onion thrips on pea and cabbage leaves. In our experiment, the concentrations of soluble sugars and sucrose in the onion leaves were significantly positively correlated with the number of onion thrips (but only in 2016), while for both years the positive correlation between the reducing sugars quantity and thrips density was confirmed. Srinivas et al. [68] and Bhonde et al. [66] also indicated that onion thrips were more attracted to onion plants when they had a high concentration of reducing sugars. The low or moderate level of reducing sugars in the leaves of cultivar Tęcza, resistant to thrips infestation, and cultivars Bila, Kristine, and Wenta with lower thrips density probably could contribute to this resistance. In turn, the increasing concentrations of soluble sugars and sucrose significantly decreased thrips damage only in 2015. This fact, and the highest content of soluble sugars and sucrose in leaves of Wenta in 2015, is likely to be one of the causes of resistance to thrips damage of this variety, although this was not confirmed in the results obtained in 2016.

In addition to sugars, phenolic compounds are also implicated as being involved in conferring resistance to thrips [69]. Phenolic groups of secondary metabolites such as flavonoids, tannins, and related phenolic precursors are widely reported as playing a significant role in defense against insect herbivores [70]. Ahmed et al. [71] and Bhonde et al. [66] indicated that free and bound phenolic contents showed a negative correlation with the number of onion thrips in bread wheat and onion cultivars, respectively. Njau et al. [40] and Akhtari et al. [72] found that phenolic concentrations in onion and Persian leek accessions, respectively, showed a significant adverse effect on onion thrips damage. Kandakoor et al. [64] and Agbahoungba et al. [63] described a similar effect of phenolics content on thrips damage to peanuts. The results obtained in this study confirm the research findings of the above-mentioned authors. It can be suspected that the reason for the resistance of $\mathrm{cv}$. Wenta to thrips damage could be the higher phenolic content in its leaves, compared to other more damaged varieties. The difference in the degree of leaf damage between cultivars harboring thrips populations of similar density, as exemplified by Wenta and Kristine, could be explained at least partially by the fact that Wenta had the highest concentrations of total phenols in the leaves, while Kristine had the lowest. The low quantity of phenolics in the cv. Tęcza leaves in 2015 could also explain its high susceptibility to thrips damage in that year. However, it is not clear why the higher level of phenolic content in the leaves of this variety in 2016 did not significantly reduce the degree of its damage in that year.

Plant phenolic compounds are accumulated in the vacuoles and kept reduced by antioxidants [73]. After plant cells are ingested by thrips, the released phenolic compounds become susceptible to autooxidation or are oxidized by salivary oxidases, as in the case of aphids [73]. Plant phenols are often bitter in taste, which effectively protects plants against herbivores. Others may act as a chemical defense due to the prooxidative effect of some of their derivatives; e.g., chlorogenic acid is oxidized to chlorogenoquinone, which, by binding to free amino acids and proteins, reduces the bioavailability of amino acids and hinders the digestion of food proteins [74]. This negative effect of this compound on western flower thrips and aphids has been detected by Leiss et al. [75] and Miles and Oertli [76], respectively. Phenolics are also known for their role in plant defense by mechanically hindering the feeding of insects with piercing-sucking mouthparts. Feruloyl quinic acid is a precursor of lignin, conferring rigidity to cell walls, which has been linked to resistance to cereal aphids [77]. In conclusion, we state that the correlative roles of phenolic compounds in thrips resistance should be characterized further by isolating these compounds from the onion germplasm and conducting bioassays with onion thrips. Moreover, the effect of phenolic compounds on herbivores will also depend on their quantity in the plant tissue. 
Thrips feeding can also induce the build-up of total phenolic contents in onion, as documented by Srinivas et al. [68]. According to Ananthakrishnan et al. [78], increased production of phenolics and alterations in the composition of phenolic acids and flavonoids in castor and eucalyptus as responses to infestations of black wine thrips, Retithrips syriacus (Mayet) can be considered manifestations of induced resistance. We also reported an increase in concentrations of total phenolic content in leaves damaged by onion thrips. Perhaps the weaker increase in the phenolic contents in the leaves of Polanowska (in 2015) and Kristine and Niagara $F_{1}$ (in 2016) reflect the weaker defense mechanism of these cultivars in response to the attack by onion thrips.

According to some authors, in resistant plants, besides the presence or absence of certain biochemical compounds or their appearance in response to pest feeding, certain morphological and/or anatomical traits may discourage or hinder a longer and deeper penetration of the leaf tissue by thrips during which insects take up the nutrients they need to survive and develop. The onion thrips population was found to be positively correlated with the thickness of the leaf blade of cotton plants [79]. Contradictory findings have been reported by Raza et al. [80] and Bowman and McCarty [81] who advocated that the thickness of leaf blade and lower epidermis correlated negatively with thrips population in different cotton lines. As well, in the case of onion cultivars, Hanafy et al. [82] reported that the thickness of the epidermis of less infested by onion thrips cv. Red onion) was higher than that on cv. Giza 20 with a higher number of thrips. Abdel-Gawaad et al. [83] suggested that the thick epidermis limited the penetration depth of the mandibles and maxillae during feeding, but several studies have shown that maxillary stylets of several species can extend beyond this distance [84]. According to Chisholm and Lewis [6], the maximum recorded length of maxillary stylet protraction is $27 \mu \mathrm{m}$ in adult onion thrips, but this length was measured on dead specimens and is probably longer in living specimens, so it seems that mesophyll cells were available for onion thrips in all tested onion cultivars. The thickest epidermis layer was noted for three cultivars, namely Bila, Karmen, and Kristine, the last two of which were found to be the most damaged by onion thrips. Moreover, the largest perimeter and area of epidermal and mesophyll cells) were found in the most damaged (cv. Kristine). On the contrary, the thinnest epidermis was observed in cv. Wenta, which was the most resistant to thrips damage in 2016. Onion thrips may have an affinity for onion cultivars with larger epidermal and mesophyll cells that contain more water and nutrients. The significant and positive correlation between the damaged leaf area and the size of the mesophyll cell seem to confirm this hypothesis, but more detailed work is required.

As previous studies revealed, there is a correlation between thrips infestation and leaf vascular bundle structure. Hanafy et al. [82] indicated that the number of xylem vessels was higher in the onion blade of cv. Red onion, resistant to onion thrips infestation, in comparison to susceptible cv. Giza. Nevertheless, there is still no firm evidence of whether thrips feed on vascular bundles, and such a possibility is only indicated by the studies of Harrewijn et al. [85]. According to Kucharczyk et al. [86], chrysanthemum thrips, Thrips nigropilosus Uzel does not damage vascular bundles while feeding on peppermint leaves. The authors assumed that this was probably associated with the fact that the outer walls of the epidermal cells at the sites of vascular bundles were covered by a thicker cuticle layer than on other cells of leaf epidermis. In our research, we found negative relationships between the number of thrips and all vascular bundle parameters, yet the only correlation between the density of thrips and the mean area of vascular bundles was found to be significant. In turn, the diameter, perimeter, and mean cross-sectional area of vascular bundles are inversely (but not significantly) correlated with the severity of injury caused by thrips feeding. The effect of the size and number of vascular bundles and other cells parameters on thrips feeding requires further and more detailed studies and the results obtained in this study should be treated with great caution, as they concern only one year of research. 
During their feeding on host plants, thrips take in carbohydrates, protein, lipids, vitamins, water, inorganic salts, and other nutrients [4]. This may affect plant nutrition and may also lead to compensation, eventually affecting the tolerance [87]. Johari et al. [88] noted that the level of carbohydrates in chili leaves attacked by thrips was reduced by $2.5 \%$ in comparison to uninfested leaves. A decrease in the concentration of reducing sugars in banana flowers damaged by banana flower thrips, Thrips hawaiiensis Morgan was reported by Yu et al. [89]. In our study, onion thrips affected the nutritional quality of the onion leaves by reducing the content of total soluble sugars and sucrose in all tested cultivars, from $7 \%$ to $29.7 \%$, while the contents of reducing sugars varied depending on the cultivar-ranging from an increase of more than $59 \%$ to a decrease of $13 \%$. The reductions of total soluble sugars and sucrose in leaves were demonstrated independently of thrips populations and the percentage of damaged leaf area of the onion cultivars tested and a similar decrease was observed for example in resistant cv. Wenta and susceptible cultivars Alibaba and Karmen. In turn, in cultivars like Polanowska, Wenta, and Tęcza, the increase in the contents of reducing sugars was higher than $25 \%$ in some years. According to Strauss and Agrawal [90], in many plant species, partial defoliation leads to an increased photosynthetic rate in the remaining plant tissues, suggesting that compensatory photosynthesis is a common physiological response to leaf damage [91]. In conclusion, the different reactions of onion cultivars to injury caused by injuries caused by thrips probably depended on the tolerance of the host plant, but to confirm this mechanism separate tests should be performed under controlled conditions with the same pest pressure.

Damage to plant tissue caused by thrips is often accompanied by ingestion of chloroplast and degradation of chlorophyll and carotenoids [6,92]. In the experiment of Dai et al. [92], chlorophyll a, b and carotenoids were significantly reduced with increased onion thrips damage in leaves of St John's wort (up to 42.6\%, 53.0\%, and 63.94\%, respectively). Thrips attacks on chili leaves reduced the chlorophyll content by 8\% [88]. According to Naidu et al. [93], the reduced level of chlorophylls, particularly chlorophyll a which is more directly involved in determining photosynthetic activity [94] may reduce rates of photosynthesis. In our study, the feeding activity of onion thrips caused a decrease in the contents of leaf pigments in all onion cultivars, from about $1 \%$ to more than $28 \%$, but the reduction was not always related to the extent of the injuries caused by thrips. The reduction of chlorophyll a was even above $20 \%$, as in the case of cv. Tecza in 2016 . However, despite such a large decrease in chlorophyll a, a high increase in the content of reducing sugars was noticed in the leaves of Tęcza, which might suggest that its tolerance is induced by an increase in the rate of photosynthesis, leading to increased glucose production.

\section{Conclusions}

A clear conclusion from this study is that thrips damage cannot always be predicted accurately based on the number of thrips, although in many onion cultivars, a higher population of onion thrips promotes more extensive (and more severe) plant injuries caused by thrips. We identified two cultivars Tęcza and Wenta useful for host resistance to thrips abundance and Wenta to thrips feeding damage and we suggest a link between concentrations of carbohydrates and phenolics and antixenotic and/or antibiotic resistance so that breeding for host plant resistance can be advanced more quickly. A positive correlation between the concentrations of the reducing sugars and thrips abundance and conversely negative relationships between the total phenolic content and thrips damage was confirmed from data for both years. However, determining the qualitative and quantitative composition of sugars and phenolics in the leaves of onion cultivar varieties may reveal their role in the resistance of the onion plant to thrips. In turn, the increasing concentrations of total soluble sugars and sucrose significantly decreased thrips damage-but only in 2015. Because of the discrepancy in the results between the two years of this study, the role of total soluble sugars and sucrose for thrips resistance must be interpreted with caution. We suspect that a thinner epidermal layer, a smaller area of epidermal and mesophyll cells, and a smaller diameter of vascular bundles may favor the resistance of onion cultivars to 
thrips, but further and more detailed studies are required to confirm this hypothesis. Thrips foraging resulted in a decrease in the content of total soluble sugars, sucrose, and plant pigments in the leaves of all onion varieties (except for chlorophyll b in cv. Polanowska in 2016), and their reductions were demonstrated independently of thrips populations and damaged leaf area. Inversely, some cultivars, namely, Polanowska, Tecza, and Wenta, reacted to the thrips attack with a high increase in reducing sugar content, which was probably due to their tolerance to thrips' feeding.

We suggest that cv. Wenta, which was resistant to abundance, and feeding damage to onion thrips should be recommended for onion growers and breeders, and we believe that both Wenta and Teecza should be further investigated for the presence of traits that support their lower infestation and/or injury levels.

Supplementary Materials: The following supporting information can be downloaded at: https: / www.mdpi.com/article/10.3390/agronomy12010147/s1, Figure S1. Rainfall and average daily temperature at the experimental site (Mydlniki, Krakow District, Poland) in the seasons 2015 and 2016. Figure S2. Dynamics population of Thrips tabaci (adults and larvae) throughout the whole growing season on onion cultivars in 2015. Figure S3. Mean percentage of damaged leaf area caused by feeding Thrips tabaci throughout the whole growing season on onion cultivars in 2015. Figure S4. Dynamics population of Thrips tabaci (adults and larvae) throughout the whole growing season on onion cultivars in 2016. Figure S5. Mean percentage of damaged leaf area caused by feeding Thrips tabaci throughout the whole growing season on onion cultivars in 2016. Table S1. Significance of sources of variation in one-way ANOVA for a mean number of adult thrips during onion plants colonization, the seasonal mean number of thrips (adults + larvae) throughout the all growing season from tested onion cultivars, and seasonal mean percentage of damaged leaf area caused by feeding thrips in 2015 and 2016, df = 7. Table S2. Significance of sources of variation in one-way ANOVA for a mean number of thrips (adults + imago) collected from tested onion cultivars and mean percentage of damaged leaf area caused by feeding thrips in subsequent days of observation in 2015 and 2016, $\mathrm{df}=7$. Table S3. Pearson's correlation between anatomical characteristics of onion leaves and the number of Thrips tabaci and percentage of damaged leaf area of onion leaves in $2016(n=8)$. Table S4. The contents of sugars and total phenols in damaged by Thrips tabaci leaves of the tested onion cultivars in 2015, $\mathrm{df}=7$. Table S5. The contents of sugars and total phenols in damaged by Thrips tabaci leaves of the tested onion cultivars in 2016. Table S6. The contents of chlorophyll a and b and the sum of carotenoids in not damaged and damaged by Thrips tabaci leaves of the tested onion cultivars in 2015, $\mathrm{df}=7$. Table S7. The contents of chlorophyll $\mathrm{a}$ and $\mathrm{b}$ and the sum of carotenoids in not damaged and damaged by Thrips tabaci leaves of the tested onion cultivars in 2016, $\mathrm{df}=7$. Table S8. Significance of sources of variation in two-way for biochemical parameters of leaves of tested onion cultivars in 2015 and 2016.

Author Contributions: Conceptualization, M.P.; methodology, M.P., M.O., E.H.-F., A.K.-G. and M.K.; software, T.W.; validation, M.P., M.O., T.W., E.H.-F. and A.K.-G.; formal analysis, M.P.; investigation, M.P., M.O., I.K., A.K.-G. and M.K.; resources, T.W. and M.P.; data curation, M.P. and M.O.; writing-original draft preparation, M.P. and M.O.; writing-review and editing, M.P. and T.W.; visualization, T.W., M.P. and M.O.; supervision, M.P.; project administration, M.P. All authors have read and agreed to the published version of the manuscript.

Funding: This research was supported by the Ministry of Science and Higher Education of Poland as a part of a research subsidy to the University of Agriculture in Krakow (DS-3508/WBiO).

Institutional Review Board Statement: All animal work was conducted according to relevant national and international guidelines. For insect collection, no permits were required since the area where thrips were collected did not contain any strictly protected areas, and Thrips tabaci is not under protection in Europe. Also, no permits were required to use insects for experiments due to the observational nature of the data collection. Formal agreements for the experiment were obtained from the University of Agriculture in Krakow.

Data Availability Statement: The data presented in this study are openly available in Harvard Dataverse: https:/ / doi.org/10.7910/DVN/BOROTC, accessed date 20 November 2021. 
Acknowledgments: We would like to thank to Joseph William Woodborn for proofreading this manuscript.

Conflicts of Interest: The authors declare no conflict of interest. The funders had no role in the design of the study; in the collection, analyses, or interpretation of data; in the writing of the manuscript, or in the decision to publish the results.

\section{References}

1. World Onion Production by Country. 2020. Available online: https://www.Atlasbig.Com/En-Ca/Countries-By-OnionProduction (accessed on 2 August 2021).

2. Eurostat 2020. Available online: https://ec.europa.eu/Info/Departments/Eurostat-European-Statistics_Pl (accessed on 26 February 2021).

3. Diaz-Montano, J.; Fuchs, M.; Nault, B.A.; Fail, J.; Shelton, A.M. Onion thrips (Thysanoptera: Thripidae): A global pest of increasing concern in onion. J. Econ. Entomol. 2011, 104, 1-13. [CrossRef] [PubMed]

4. Lewis, T. Pest thrips in perspective. In Thrips as Crop Pests; Lewis, T., Ed.; CAB International: New York, NY, USA, 1997 ; pp. 1-13.

5. Szwejda, J.; Wrzodak, R. Phytophagous entomofauna occurring on onion plantations in Poland in years 1919-2007. J. Fruit Ornam. Plant Res. 2009, 71, 5-14. [CrossRef]

6. Chisholm, I.F.; Lewis, T. A new look at thrips (Thysanoptera) mouthparts, their action and effects of feeding on plant tissue. Bull. Entomol. Res. 1984, 74, 663-675. [CrossRef]

7. Kindt, F.; Joosten, N.N.; Tjallingii, W.F. Electrical penetration graphs of thrips revised: Combining DC-and AC-EPG signals. J. Insect Physiol. 2006, 52, 1-10. [CrossRef] [PubMed]

8. Boateng, C.O.; Schwartz, H.F.; Havey, M.J.; Otto, K. Evaluation of onion germplasm for resistance to Iris yellow spot (Iris yellow spot virus) and onion thrips, Thrips tabaci. Southwest Entomol. 2014, 39, 237-260. [CrossRef]

9. Ghosheh, H.Z.; Al-Shannag, H.K. Influence of weeds and onion thrips, Thrips tabaci (Thysanoptera: Thripidae), on Onion Bulb Yield in Jordan. Crop Prot. 2000, 19, 175-179. [CrossRef]

10. Rueda, A.; Badenes-Perez, F.R.; Shelton, A.M. Developing economic thresholds for onion thrips in Honduras. Crop Prot. 2007, 26, 1099-1107. [CrossRef]

11. Fournier, F.; Boivin, G.; Stewart, R.K. Effect of Thrips tabaci (Thysanoptera: Thripidae) on yellow onion yields and economic thresholds for its management. J. Econ. Entomol. 1995, 88, 1401-1407. [CrossRef]

12. Waiganjo, M.M.; Gitonga, L.M.; Mueke, J.M. Effects of weather on thrips population dynamics and its implications on the thrips pest management. J. Hortic. Sci. 2008, 1, 82-90.

13. Diaz-Montano, J.; Fuchs, M.; Nault, B.A.; Fail, J.; Shelton, A.M. Evaluation of onion cultivars for resistance to onion thrips (Thysanoptera: Thripidae) and Iris yellow spot virus. J. Econ. Entomol. 2010, 103, 925-937. [CrossRef]

14. Dutta, B.; Barman, A.K.; Srinivasan, R.; Avci, U.; Ullman, D.E.; Langston, D.B.; Gitaitis, R.D. Transmission of Pantoea ananatis and P. agglomerans, causal agents of center rot of onion (Allium cepa), by onion thrips (Thrips tabaci) through feces. Phytopathology 2014, 104, 812-819. [CrossRef] [PubMed]

15. Thind, T.S.; Jhooty, J.S. Association of thrips with purple blotch infection on onion plants caused by Alternaria porri. Indian Phytopathol. 1982, 35, 696-698.

16. Alston, D.G.; Drost, D. Onion thrips (Thrips tabaci). ENT-117-08PR. Utah Pests Fact Sheet, Utah State University Extension. Utah State University Extension and Utah Plant Pest Diagnostic Laboratory, Logan, UT. 2008. Available online: http://extension.usu. edu/Files/Publications/Factsheet/Ent-117-08pr.Pdf (accessed on 25 February 2021).

17. Allen, J.K.M.; Scott-Dupree, C.D.; Tolman, J.H.; Harris, C.R. Resistance of Thrips tabaci to pyrethroid and organophosphorus insecticides in Ontario, Canada. Pest Manag. Sci. 2005, 61, 809-815. [CrossRef]

18. Shelton, A.M.; Zhao, J.Z.; Nault, B.A.; Plate, J.; Musser, F.R.; Larentzaki, E. Patterns of Insecticide Resistance in Onion Thrips (Thysanoptera: Thripidae) in Onion Fields in New York. J. Econ. Entomol. 2006, 99, 1798-1804. [CrossRef] [PubMed]

19. Adesanya, A.W.; Waters, T.D.; Lavine, M.D.; Walsh, D.B.; Lavine, L.C.; Zhu, F. Multiple insecticide resistance in onion thrips populations from Western USA. Pestic. Biochem. Physiol. 2020, 165, 104553. [CrossRef]

20. Moretti, E.A.; Harding, R.S.; Scott, J.G.; Nault, B.A. Monitoring onion thrips (Thysanoptera: Thripidae) susceptibility to spinetoram in New York onion fields. J. Econ. Entomol. 2019, 112, 1493-1497. [CrossRef]

21. Barzman, M.; Barberi, P.; Birch, N.; Boonekamp, P.; Dachbrodt-Saaydeh, S.; Graf, B.; Hommel, B.; Jensen, J.E.; Kiss, J.; Kudsk, P.; et al. Eight principles of Integrated Pest Management. Agron. Sustain. Dev. 2015, 35, 1199-1215. [CrossRef]

22. Smith, C.M. Plant Resistance to Arthropods: Molecular and Conventional Approaches, 1st ed.; Springer Science \& Business Media: Dordrecht, The Netherlands, 2005.

23. Capinera, J.L. Integrated pest management: Current concepts and ecological perspective. Fla. Entomol. 2014, 97, 1272. [CrossRef]

24. Kogan, M.; Ortman, E.F. Antixenosis-A new term proposed to define Painter's "nonpreference" modality of resistance. Bull. Entmol. Soc. Am. 1978, 24, 175-176. [CrossRef]

25. Painter, R.H. Insect Resistance in Crop Plants; Macmillan: New York, NY, USA, 1951. [CrossRef] 
26. Diaz-Montano, J.; Fail, J.; Deutschlander, M.; Nault, B.A.; Shelton, A.M. Characterization of resistance, evaluation of the attractiveness of plant odors, and effect of leaf colour on different onion cultivars to onion thrips (Thysanoptera: Thripidae). J. Econ. Entomol. 2012, 105, 632-641. [CrossRef]

27. Fail, J.; Deutschlander, M.E.; Shelton, A.M. Antixenotic resistance of cabbage to onion thrips (Thysanoptera: Thripidae). I. Light reflectance. J. Econ. Entomol. 2013, 106, 2602-2612. [CrossRef]

28. Koschier, E.H.; Sedy, K.A.; Novak, J. Influence of plant volatiles on feeding damage caused by the onion thrips Thrips tabaci. Crop Prot. 2002, 21, 419-425. [CrossRef]

29. Brown, A.S.S.; Simmonds, M.S.; Blaney, W.M. Relationship between nutritional composition of plant species and infestation levels of thrips. J. Chem. Ecol. 2002, 28, 2399-2409. [CrossRef] [PubMed]

30. Pobożniak, M.; Koschier, E.H. Effects of pea (Pisum sativum L.) cultivars on Thrips tabaci Lindeman preference and performance. J. Agric. Sci. 2014, 152, 885-893. [CrossRef]

31. Leiss, K.A.; Cristofori, G.; van Steenis, R.; Verpoorte, R.; Klinkhamer, P.G. An eco-metabolomic study of host plant resistance to western flower thrips in cultivated, biofortified and wild carrots. Phytochemistry 2013, 93, 63-70. [CrossRef] [PubMed]

32. Steenbergen, M.; Abd-el-Haliem, A.; Bleeker, P.; Dicke, M.; Escobar-Bravo, R.E.R.; Cheng, G.; Haring, M.A.; Kant, M.R.; Kappers, I.; Klinkhamer, P.G.L.; et al. Thrips advisor: Exploiting thrips-induced defenses to combat pests on crops. J. Exp. Bot. 2018, 69, 1837-1848. [CrossRef]

33. Morsello, S.C.; Groves, R.L.; Nault, B.A.; Kennedy, G.G. Temperature and precipitation affect seasonal patterns of dispersing tobacco thrips, Frankliniella fusca, and onion thrips, Thrips tabaci (Thysanoptera: Thripidae) caught on sticky traps. Environ. Entomol. 2008, 37, 79-86. [CrossRef]

34. Fok, E.J.; Petersen, J.D.; Nault, B.A. Relationships between insect predator populations and their prey, Thrips tabaci, in onion fields grown in large-scale and small-scale cropping systems. BioControl 2014, 59, 739-748. [CrossRef]

35. Mala, B.; Nighot, P. Natural enemy complex of Thrips tabaci Lindeman in onion and garlic. Pest Manag. Hort. Ecosyst. 2013, 19, 121-122.

36. Damon, S.J.; Groves, R.L.; Havey, M.J. Variation for epicuticular waxes on onion foliage and impacts on numbers of onion thrips. J. Am. Soc. Hortic. Sci. 2014, 139, 495-501. [CrossRef]

37. Munaiz, E.D.; Groves, R.L.; Havey, M.J. Amounts and types of epicuticular leaf waxes among onion accessions selected for reduced damage by onion thrips. J. Am. Soc. Hortic. Sci. 2020, 145, 30-35. [CrossRef]

38. da Silva, V.C.P.; Bettoni, M.M.; Bona, C.; Foerster, L.A. Morphological and chemical characteristics of onion plants (Allium cepa L.) associated with resistance to onion thrips. Acta Sci. Agron. 2014, 37, 85-92. [CrossRef]

39. Alimousavi, S.A.; Hassandokht, M.R.; Moharramipour, S.A.E.I.D. Evaluation of Iranian onion germplasms for resistance to thrips. Int. J. Agric. Biol. 2007, 9, 897-900.

40. Njau, G.M.; Nyomora, A.M.; Dinssa, F.F.; Chang, J.C.; Malini, P.; Subramanian, S.; Srinivasan, R. Evaluation of onion (Allium cepa) germplasm entries for resistance to onion thrips, Thrips tabaci (Lindeman) in Tanzania. Int. J. Trop. Insect Sci. 2017, 37, 98-113. [CrossRef]

41. Pobożniak, M.; Leśniak, M.; Chuda, A.; Adamus, A. Field assessment of the susceptibility of onion cultivars to thrips attackpreliminary results. Pol. J. Entomol. 2016, 85, 121-133. [CrossRef]

42. Pobożniak, M.; Olczyk, M.; Wójtowicz, T. Relationship between colonization by onion thrips (Thrips tabaci Lind.) and leaf colour measures across eight onion cultivars (Allium cepa L.). Agronomy 2021, 11, 963. [CrossRef]

43. Zawirska, I. Thrips (Thysanoptera). In Diagnostics of Plant Pests and Their Natural Enemies; Kozłowski, M.W., Boczek, J., Eds.; SGGW: Warsaw, Poland, 1994; pp. 145-174.

44. Strassen, R.Z. Die terebranten thysanopteren Europas und des Mittelmeer-Gebietes. Tierwelt Dtschl. $2003,74,1-277$.

45. Kucharczyk, H. Comparative Morphology of the Second Larval Instar of the Thrips Genus Species (Thysanoptera: Thripidae) Occurring in Poland; Mantis: Olsztyn, Poland, 2010; ISBN 978-83-929997-7-5.

46. Edelson, J.V.; Magaro, J.J. Development of onion thrips, Thrips tabaci Lindeman, as a function of temperature. Southwest Entomol. $1988,13,171-176$

47. Murai, T. Effect of temperature on development and reproduction of the onion thrips, Thrips tabaci Lindeman (Thysanoptera: Thripidae), on pollen and honey solution. Appl. Entomol. Zool. 2000, 35, 499-504. [CrossRef]

48. Samotus, B.; Tuz, J.; Doerre, E. Evaluation of Blue Value in different plant materials as a tool for rapid starch determination. Acta Soc. Bot. Pol. 1993, 62, 137-141. [CrossRef]

49. Nath, N.; Singh, M.P. Mechanism of the oxidation of reducing sugars (hexoses) by hexacyanoferrate (III) in alkaline medium and Lobry de Bruyn transformation. J. Phys. Chem. 1965, 69, 2038-2043. [CrossRef]

50. Singleton, V.L.; Rossi, J.A. Colorimetry of total phenolics with phosphomolybdic-phosphotungstic acid reagents. Am. Soc. Enol. Vitic. 1965, 16, 144-158.

51. Lichtenthaler, H.K. Chlorophylls and carotenoids: Pigments of photosynthetic biomembranes. Methods Enzymol. 1987, 148, 350-382. [CrossRef]

52. Knolhoff, L.; Heckel, D.G. Behavioral assays for studies of host plant choice and adaptation in herbivorous insects. Ann. Rev. Entomol. 2014, 59, 263-278. [CrossRef]

53. Bálint, J.; Burghardt, N.; Höhn, M.M.; Pénzes, B.; Fail, J. Does epidermal thickness influence white cabbage resistance against onion thrips (Thrips tabaci)? Not. Bot. Horti Agrobot. Cluj-Napoca 2013, 41, 444-449. [CrossRef] 
54. Terry, L.I. Host Selection, Communication and Reproductive Behaviour. In Thrips as Crop Pests; Lewis, T., Ed.; CAB International: Wallingford, UK, 1997; pp. 65-118.

55. Cramer, C.S.; Singh, N.; Kamal, N.; Pappu, H.R. Screening onion plant introduction accessions for tolerance to onion thrips and iris yellow spot. Hortic. Sci. 2014, 49, 1253-1261. [CrossRef]

56. Eigenbrode, S.D.; Castagnola, T.; Roux, M.B.; Steljes, L. Mobility of three generalist predators is greater on cabbage with glossy leaf wax than on cabbage with a wax bloom. Entomol. Exp. Appl. 1996, 81, 335-343. [CrossRef]

57. Trdan, S.; Znidarcic, D.; Zlatic, E.; Jerman, J. Correlation between epicuticular wax content in the leaves of early white cabbage (Brassica oleracea L. var. capitata) and damage caused by Thrips tabaci Lindeman (Thysanoptera: Thripidae). Acta Phytopathol. Entomol. Hung. 2004, 39, 173-185. [CrossRef]

58. Voorrips, R.E.; Steenhuis-Broers, G.; Tiemens-Hulscher, M.; Lammerts van Bueren, E.T. Earliness, leaf surface wax and sugar content predict varietal differences for thrips damage in cabbage. In Proceedings of the 5th International Symposium on Brassicas and 16th Crucifer Genetics Work Shop, Lillehammer, Norway, 8-12 September 2008; Acta Hort: Lillehammer, Norway, 2010; Volume 867, pp. 127-132. [CrossRef]

59. Lewis, T. Thrips, Their Biology, Ecology and Economic Importance, 1st ed.; Academic Press: London, UK, 1973 ; p. 349.

60. Mollema, C.; Steehuis, G.; Ingammer, H. Genotypic effect of cucumber responses to infestation by western flower thrips. In Thrips Biology and Management; Parker, B.L., Skinner, M., Lewis, T., Eds.; Plenum Press: New York, NY, USA, 1995 ; pp. 397-401. [CrossRef]

61. Miyazaki, J.; Stiller, W.N.; Wilson, L.J. Sources of plant resistance to thrips: A potential core component in cotton IPM. Entomol. Exp. Appl. 2016, 162, 30-40. [CrossRef]

62. Ananthakrishnan, T.N.; Gopichandran, R. Chemical Ecology in Thrips-Host Plant Interactions; Oxford \& IBH Publishers: New Delhi, India, 1993.

63. Agbahoungba, S.; Karungi, J.; Badji, A.; Sadik, K.; Gibson, P.; Edema, R.; Assogbadjo, A.E.; Rubaihayo, P.R. Inheritance of cowpea resistance to flower thrips in Uganda germplasm. J. Plant Breed. Crop Sci. 2018, 10, 21-32. [CrossRef]

64. Kandakoor, S.B.; Khan, H.K.; Chakravarthy, A.K.; Kumar, C.A.; Venkataravana, P. Biochemical constituents influencing thrips resistance in groundnut germplasm. J. Environ. Biol. 2014, 35, 675-681. [PubMed]

65. Chandrayudu, E.; Vemena, K.; Naik, B.S.; Prathyusha, C. Biophysical and biochemical constituents influencing thrips and jassid resistance in groundnut germplasm. In Natural Resource Management: Ecological Perspectives, Proceedings of the Indian Ecological Society International Conference, Jammu, India, 18-20 February 2016; Peshin, R., Dhawan, A.K., Bano, F., Risam, K.S., Eds.; The Indian Ecological Society: Jammu, India, 2016; Volume 2, pp. 780-782.

66. Bhonde, B.N.; Pawar, D.B.; Nikam, D.P. Role of biochemicals in imparting resistance in onion against onion thrips Thrips tabaci Lindeman. Adv. Life Sci. 2016, 5, 8798-8800.

67. Žnidarčič, D.; Vidrih, R.; Germ, D.; Ban, D.; Trdan, S. Relationship between water-soluble carbohydrate composition of cabbage (Brassica oleracea L. var. capitata) and damage levels of onion thrips. Acta Agric. Slov. 2007, 89, 25-33. [CrossRef]

68. Srinivas, P.S.; Aziz Qureshi, A.; Lawande, K.E. Growth stage susceptibility of onion (Allium cepa) and its role in thrips management. Indian J. Agric. Sci. 2008, 78, 98-101.

69. Bennett, R.N.; Wallsgrove, R.M. Secondary metabolites in plant defense mechanisms. New Phytol. 1994, 127, 617-633. [CrossRef] [PubMed]

70. Treutter, D. Significance of flavonoids in plant resistance: A review. Environ. Chem. Lett. 2006, 4, 147-157. [CrossRef]

71. Ahmed, A.; Radi, A.; Tolba, E. Efficiency of phenolic contents and some field factors on the population abundance of aphid species and onion thrips infesting bread wheat cultivars under irrigation conditions. J. Plant Prot. Pathol. 2019, 10, 69-75. [CrossRef]

72. Akhtari, M.; Dashti, F.; Madadi, H.; Rondon, S. Evaluation of resistance to onion thrips (Thrips tabaci Lind.) in several Tareh Irani (Persian leek: Allium ampeloprasum Tareh group) landraces. Arch. Phytopathol. Plant Prot. 2014, 47, 29-41. [CrossRef]

73. Miles, P.W. Aphid saliva. Biol. Rev. Camb. Philos. Soc. 1999, 74, 41-85. [CrossRef]

74. Felton, G.W.; Donato, K.K.; Broadway, R.M.; Duffey, S.S. Impact of oxidized plant phenolics on the nutritional quality of dietary protein to a noctuid herbivore, Spodoptera exigua. J. Insect Physiol. 1992, 38, 277-285. [CrossRef]

75. Leiss, K.A.; Choi, Y.H.; Abdel-Farid, I.B.; Verpoorte, R.; Klinkhamer, P.G. NMR metabolomics of thrips (Frankliniella occidentalis) resistance in Senecio hybrids. J. Chem. Ecol. 2009, 35, 219-229. [CrossRef]

76. Miles, P.W.; Oertli, J.J. The significance of antioxidants in the aphid-plant interaction: The redox hypothesis. Entomol. Exp. Appl. 1993, 67, 275-283. [CrossRef]

77. Havlíčková, H.; Cvikrová, M.; Eder, J. Phenolic acids in wheat cultivars in relation to plant suitability for and response to cereal aphids. J. Plant Dis. Prot. 1996, 103, 535-542.

78. Ananthakrishnan, T.N.; Gopichandran, R.; Gurusubramanian, G. Influence of chemical profiles of host plants on the infestation diversity of Retithrips syriacus. J. Biosci. 1992, 17, 483-489. [CrossRef]

79. Khalil, H.; Raza, A.B.M.; Afzal, M.; Aqueel, M.A.; Khalil, M.S.; Mansoor, M.M. Effects of plant morphology on the incidence of sucking insect pests complex in few genotypes of cotton. J. Saudi Soc. Agric. Sci. 2017, 16, 344-349. [CrossRef]

80. Raza, A.B.M.; Afzal, M.; Sarfraz, M.; Bashir, M.H.; Gogi, M.D.; Sarwar, M.S. Physico-morphic plant characters in relation to resistance against sucking insect pests in some new cotton genotypes. Pak. Entomol. 2000, 22, 73-77.

81. Bowman, D.T.; McCarty, J.C., Jr. Thrips (Thysanoptera: Thripidae) tolerance in cotton: Sources and heritability. J. Entomol. Sci. 1997, 32, 460-471. [CrossRef] 
82. Hanafy, A.R.I.; Tahany, R.A.; Nowar, E.E.; Hasan, S.M. Effect of anatomical and phytochemical diversity of two onion cultivars on the infestation with onion thrips (Thysanoptera: Thripidae). Middle East J. Appl. Sci. 2016, 6, 941-948.

83. Abdel-Gawaad, A.A.W.; El-Gayar, F.H.; Soliman, A.S.; Zaghlool, O.A. Studies on Thrips tabaci Lindman: X. Mechanism of resistance to Thrips tabaci L. in cotton varieties. J. Appl. Entomol. 1973, 73, 251-255. [CrossRef]

84. Childers, C.C.; Achor, D.S. Feeding and oviposition injury to flowers and developing floral buds of 'Navel' orange by Frankliniella bispinosa (Thysanoptera: Thripidae) in Florida. Ann. Entomol. Soc. Am. 1991, 84, 272-282. [CrossRef]

85. Harrewijn, P.; Tjallingii, W.F.; Mollema, C. Electrical recording of plant penetration by western flower thrips. Entomol. Exp. Appl. 1996, 79, 345-353. [CrossRef]

86. Kucharczyk, H.; Kucharczyk, M.; Winiarczyk, K.; Lubiarz, M.; Tchórzewska, D. Effects of temperature on the development of Thrips nigropilosus Uzel (Thysanoptera: Thripidae) on Mentha $\times$ piperita L. and the impact of pest on the host plant. Acta Sci. Pol. Hortoru. Cultus 2019, 18, 219-233. [CrossRef]

87. Peterson, R.K.; Varella, A.C.; Higley, L.G. Tolerance: The forgotten child of plant resistance. Peer J. 2017, 5, e3934. [CrossRef]

88. Johari, A.; Herlinda, S.; Irsan, C.; Pujiastuti, Y. Phenomenon of thrips (Thysanoptera) attack on chili plant (Capsicum annuum L.). Am. J. Agric. Biol. Sci. 2016, 11, 103-109. [CrossRef]

89. Yu, D.; Huang, P.; Chen, Y.; Lin, Y.; Akutse, K.S.; Lan, Y.; Wei, H. Effects of flower thrips (Thysanoptera: Thripidae) on nutritional quality of banana (Zingiberales: Musaceae) buds. PLOS ONE 2018, 13, e0202199. [CrossRef]

90. Strauss, S.Y.; Agrawal, A.A. The ecology and evolution of plant tolerance to herbivory. Trends Ecol. Evol. 1999, 14, 179-185. [CrossRef]

91. Tiffin, P. Mechanisms of tolerance to herbivore damage: What do we know? Evol. Ecol. 2000, 14, 523-536. [CrossRef]

92. Dai, Y.; Shao, M.; Hannaway, D.; Wang, L.; Liang, J.; Hu, L.; Lu, H. Effect of Thrips tabaci on anatomical features, photosynthetic characteristics and chlorophyll fluorescence of Hypericum sampsonii leaves. Crop Prot. 2009, 28, 327-332. [CrossRef]

93. Naidu, R.A.; Krishnan, M.; Nayudu, M.V.; Gnanam, A. Studies on peanut green mosaic virus infected peanut (Arachis hypogaea L.) leaves. II. Chlorophyll-protein complexes and polypeptide composition of thylakoid membranes. Physiol. Plant Pathol. 1984, 25, 191-198. [CrossRef]

94. Sestak, Z. Limitations for finding linear relationship between chlorophyll content and photosynthetic activity. Biol. Plant. 1996, 8 , 336-346. [CrossRef] 